Article

\title{
In Vitro Screening of East Asian Plant Extracts for Potential Use in Reducing Ruminal Methane Production
}

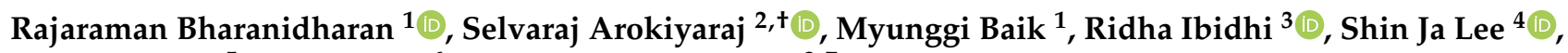 \\ Yookyung Lee ${ }^{5}$, In Sik Nam ${ }^{6}$ and Kyoung Hoon Kim ${ }^{3,7, *}$
}

1 Department of Agricultural Biotechnology, College of Agriculture and Life Sciences, Seoul National University, Seoul 08826, Korea; bharanidharan7@snu.ac.kr (R.B.); mgbaik@snu.ac.kr (M.B.)

2 Department of Food science and Biotechnology, Sejong University, Seoul 05006, Korea; arokiyaraj16@gmail.com

3 Department of Ecofriendly Livestock Science, Institute of Green Bio Science and Technology, Seoul National University, Pyeongchang 25354, Gangwon-do, Korea; ridha@snu.ac.kr

4 Institute of Agriculture and Life Science \& University-Centered Labs, Gyeongsang National University, Jinju 52828, Gyeongsangnam-do, Korea; tlswk1000@hanmail.net

5 National Institute of Animal Sciences, RDA, Jeonju 54875, Jeollabuk-do, Korea; yoo3930@korea.kr

6 Research Centre for Environment Friendly and Quality Livestock Production and Technology, Hankyoung National University, Anseong 17579, Gyeonggi-do, Korea; isnam@hknu.ac.kr

7 Department of International Agricultural Technology, Graduate School of International

Agricultural Technology, Seoul National University, Pyeongchang 25354, Gangwon-do, Korea

* Correspondence: khhkim@snu.ac.kr; Tel.: +82-33-339-5726

+ These authors contributed equally to this work.

Citation: Bharanidharan, R.; Arokiyaraj, S.; Baik, M.; Ibidhi, R.; Lee, S.J.; Lee, Y.; Nam, I.S.; Kim, K.H. In Vitro Screening of East Asian Plant Extracts for Potential Use in Reducing Ruminal Methane Production. Animals 2021, 11, 1020. https:// doi.org/10.3390/ani11041020

Academic Editor: In Ho Kim

Received: 11 March 2021

Accepted: 2 April 2021

Published: 4 April 2021

Publisher's Note: MDPI stays neutral with regard to jurisdictional claims in published maps and institutional affiliations.

Copyright: (c) 2021 by the authors. Licensee MDPI, Basel, Switzerland. This article is an open access article distributed under the terms and conditions of the Creative Commons Attribution (CC BY) license (https:/ / creativecommons.org/licenses/by/ $4.0 /)$.
Simple Summary: Methane from ruminants is a major contributor to total greenhouse gases. Therefore, ruminant nutritionists have proposed strategies to mitigate methane emissions, such as chemical inhibitors and ionophores. However, dietary manipulation including natural feed additives is more practical, considering consumer preferences. Therefore, the current experiment screened 137 plant species, indigenous to East Asian countries, to select novel anti-methanogenic candidates as natural feed additives. Among these species, an extract from the seeds of Pharbitis nil exhibited a maximum $37 \%$ reduction of methane in a conformation assay. Identification of active compounds present in the seeds of Pharbitis nil revealed enrichment of polyunsaturated fatty acids, which were dominated by linoleic acid (18:2). The extract had negative effects on the populations of ciliated protozoa and $\mathrm{H}_{2}$-producing Ruminococcus flavefaciens, thereby increasing the proportion of propionate, similar to the effect of monensin. This is the first report to suggest that the seeds of $P$. nil could be a promising anti-methanogenic alternative to ionophores or oil seeds.

Abstract: Indiscriminate use of antibiotics can result in antibiotic residues in animal products; thus, plant compounds may be better alternative sources for mitigating methane $\left(\mathrm{CH}_{4}\right)$ production An in vitro screening experiment was conducted to evaluate the potential application of 152 dry methanolic or ethanolic extracts from 137 plant species distributed in East Asian countries as antimethanogenic additives in ruminant feed. The experimental material consisted of $200 \mathrm{mg}$ total mixed ration, $20 \mathrm{mg}$ plant extract, and $30 \mathrm{~mL}$ diluted ruminal fluid-buffer mixture in $60 \mathrm{~mL}$ serum bottles that were sealed with rubber stoppers and incubated at $39^{\circ} \mathrm{C}$ for $24 \mathrm{~h}$. Among the tested extracts, eight extracts decreased $\mathrm{CH}_{4}$ production by $>20 \%$, compared to the corresponding controls: stems of Vitex negundo var. incisa, stems of Amelanchier asiatica, fruit of Reynoutria sachalinensis, seeds of Tribulus terrestris, seeds of Pharbitis nil, leaves of Alnus japonica, stem and bark of Carpinus tschonoskii, and stems of Acer truncatum. A confirmation assay of the eight plant extracts at a dosage of $10 \mathrm{mg}$ with four replications repeated on 3 different days revealed that the extracts decreased $\mathrm{CH}_{4}$ concentration in the total gas (7-15\%) and total $\mathrm{CH}_{4}$ production (17-37\%), compared to the control. This is the first report to identify the anti-methanogenic activities of eight potential plant extracts. All extracts decreased ammonia $\left(\mathrm{NH}_{3}-\mathrm{N}\right)$ concentrations. Negative effects on total gas and volatile fatty acid (VFA) production were also noted for all extracts that were rich in hydrolysable tannins and total saponins or fatty acids. The underlying modes of action differed among plants: extracts from 
P. nil, V. negundo var. incisa, A. asiatica, and R. sachalinensis resulted in a decrease in total methanogen or the protozoan population $(p<0.05)$ but extracts from other plants did not. Furthermore, extracts from $P$. nil decreased the population of total protozoa and increased the proportion of propionate among VFAs $(p<0.05)$. Identifying bioactive compounds in seeds of $P$. nil by gas chromatographymass spectrometry analysis revealed enrichment of linoleic acid (18:2). Overall, seeds of $P$. nil could be a possible alternative to ionophores or oil seeds to mitigate ruminal $\mathrm{CH}_{4}$ production.

Keywords: in vitro; screening; methane; tannin; saponin; unsaturated fatty acids; protozoa

\section{Introduction}

Ruminal methane $\left(\mathrm{CH}_{4}\right)$ production is regarded as the cause of a loss of $3-10 \%$ of the gross energy intake of the animal and leads to the unproductive use of dietary energy [1]. Concerns regarding feed energy loss and climate change have led to many scientific studies aimed at lowering enteric $\mathrm{CH}_{4}$ production by ruminants through various mitigation options [2,3]. Notably, feed additives (e.g., $\mathrm{CH}_{4}$ analogues, hydroxymethylglutaryl-CoA reductase inhibitors, and nitrate and organic nitro compounds that are capable of decreasing rumen methanogenesis) have been extensively studied over the past two decades (reviewed in [4-8]). However, the use of certain chemically modified/synthesised compounds has adverse effects on fermentation at effective concentrations [4-7]. Intriguingly, 3-nitrooxypropanol is widely regarded as a promising candidate for enteric $\mathrm{CH}_{4}$ mitigation $[9,10]$. In addition to its potential to mitigate $\mathrm{CH}_{4}$, consumer preference may factor into the acceptance of such a synthetic compound if commercially available. Furthermore, concerns have been raised regarding the potential use of antibiotics because of their residues in final products, which have led to bans in the Republic of Korea since 2011 [11,12]. Therefore, natural plant feed additives that might be environmentally friendly and have a high level of acceptance among consumers are desired to improve livestock productivity.

Several studies have suggested that adding plant essential oils or plant extracts rich in plant secondary metabolites (PSM; e.g., tannins, saponins, and flavonoids) to ruminant diets may have beneficial effects on ruminal fermentation and $\mathrm{CH}_{4}$ production (reviewed in [13-15]). A comprehensive review by Patra et al. [4] also elaborated the direct and indirect roles of such PSMs against the growth and activity of rumen methanogens and the protozoan population. Similarly, numerous studies have shown that increasing fatty acid concentrations in the diet decreases $\mathrm{CH}_{4}$ production to a greater extent, but often exerts detrimental effects on digestibility and fermentation of feeds, as well as animal performance [16-19]. Therefore, it would be desirable to discover plant-based fatty acidrich feed additives that decrease $\mathrm{CH}_{4}$ production, with additional effects of improved digestibility and animal performance.

Screening natural sources at a large scale is an initial step in the discovery and development of new compounds and feed additives. Few studies have performed screening experiments; these include the European Union project "Rumen-up" that evaluated 450 plants and plant extracts [20], 58 plants, herbs, and spices in Spain [21], 156 plants from natural grasslands in France [22], and 93 plant extracts in India [23]. Nevertheless, there is a persistent need to identify potential anti-methanogenic plants for the development of new compounds as natural feed additives, because many in vivo studies have shown adaptation of the additives by rumen microbes [24,25]. Furthermore, no study has focused on large-scale screening of plant species that are widely distributed in East Asian countries for their $\mathrm{CH}_{4}$ reduction potential. Hence, our objectives in this study were to screen 152 plant extracts from 137 plant species of East Asian origin for their potential to reduce $\mathrm{CH}_{4}$ production, in vitro; to study the effect on volatile fatty acids (VFAs) production, to quantify the bioactive compounds of the selected candidates; and to uncover their actions on methanogens, protozoa, and several other rumen cellulolytic bacteria using real-time polymerase chain reaction (PCR) analysis. 


\section{Materials and Methods}

\subsection{Plant Material}

The Plant Extract Bank at the Korea Research Institute of Bioscience and Biotechnology (Daejeon, Korea) has stocked extracts of 1714 species of native Korean plants, which comprise $41 \%$ of all Korean plant species (excluding garden plants and food crops). In total, 6016 extracts from plants that are distributed in Korea and other East Asian countries are available at the Plant Extract Bank as an easy source to discover beneficial phytochemicals. Initially, 152 plant methanolic or ethanolic extracts from 137 plant species that were indigenous to East Asian countries were obtained, and their scientific names and the plant parts used for solvent extraction are listed in Table 1.

Table 1. Scientific names, common names, and parts of plants screened in the in vitro assay.

\begin{tabular}{|c|c|c|}
\hline Scientific Names & Common Names & Parts Used ${ }^{1}$ \\
\hline Abelia mosanensis T.H.Chung ex Nakai & Sweet abelia & Stem \\
\hline Abeliophyllum distichum Nakai & White forsythia & Stem \\
\hline Abies koreana E.H.Wilson & Korean fir & Leaf \\
\hline Abies koreana E.H.Wilson & Korean fir & Stem \\
\hline Acanthopanax senticosus (Rupr. \& Maxim.) Harms & Siberian ginseng & Leaf, stem \\
\hline Acer palmatum Thunb. & Japanese maple & Leaf \\
\hline Acer pictum subsp. mono(Maxim.) H. Ohashi & Painted maple & Leaf \\
\hline Acer pseudo-sieboldianum var. koreanum Nakai & Korean maple & Leaf, stem \\
\hline Acer takesimense Nakai & Takeshima Korean maple & Leaf, stem \\
\hline Acer tataricum subsp. ginnala (Maxim.) Wesmael & Tatarian maple & Stem \\
\hline Acer tegmentosum Maxim. & Manchurian striped bark maple & Stem \\
\hline Acer triflorum Kom. & Three-flowered maple & Stem \\
\hline Acer truncatum Bunge & Shangtung maple & Stem \\
\hline Acer tschonoskii var. rubripes Kom. & Butterfly maple & Stem \\
\hline Aconitum carmichaeli Debeaux & Carmichael's monkshood & Tuber $[E]$ \\
\hline Actinodaphne lancifolia (Sieb. \& Zucc.) Meisn & Unknown & Leaf \\
\hline Adonis amurensis Regel \& Radde & Amur adonis & Aerial parts \\
\hline Allium grayi Regel & Long-stamen chive & Aerial parts \\
\hline Alnus japonica Siebold \& Zucc. & Japanese alder & Leaf \\
\hline Alnus maximowiczii Callier ex C.K.Schneid. & Montane alder & Leaf \\
\hline Amelanchier asiatica (Sieb. \& Zucc.) Endl. ex Walp. & Korean juneberry & Stem \\
\hline Amomum villosum Lour. & Bastard cardamon & Fruit $[\mathrm{E}]$ \\
\hline Ampelopsis japonica (Thunb.) Makino & Peppervine & Tuber $[\mathrm{E}]$ \\
\hline Angelica japonica A.Gray & Unknown & Leaf \\
\hline Angelica japonica A.Gray & Unknown & Stem, root \\
\hline Aralia continentalis Kitag. & Manchurian spikenard & Stem \\
\hline Ardisia crenata Sims. & Coral ardisia & Leaf \\
\hline Ardisia japonica (Thunb.) Blume & Marlberry & Leaf \\
\hline Ardisia japonica (Thunb.) Blume & Marlberry & Stem \\
\hline Areca catechu L. & Betelnut palm & Pericarp $[\mathrm{E}]$ \\
\hline Arisaema takesimense Nakai & Cobra lily & Stem \\
\hline Asarum sieboldii Miq. & Wild ginger & Aerial parts \\
\hline Atractylodes macrocephala Koidz. & Bai Zhu & Rhizome [E] \\
\hline Aucuba japonica Thunb. & Spotted laurel & Leaf \\
\hline Callicarpa japonica var. leucocarpa Siebold & Japanese beautyberry & Fruit \\
\hline Calystegia soldanella(L.) R.Br. & Sea bindweed & Aerial parts \\
\hline Camellia japonica L. & Japanese camellia & Stem \\
\hline Camellia japonica $\mathrm{L}$. & Japanese camellia & Leaf \\
\hline
\end{tabular}


Table 1. Cont.

\begin{tabular}{|c|c|c|}
\hline Scientific Names & Common Names & Parts Used ${ }^{1}$ \\
\hline Campanula takesimana Nakai & Korean bellflower & Aerial parts \\
\hline Capsella bursa-pastoris(L.) Medik. & Shepherd's purse & Aerial parts \\
\hline Cardamine amaraeformis Nakai & Brewer's bittercress & Aerial parts \\
\hline Cardamine flexuosa Withering & Wavy bittercress & Stem \\
\hline Carpinus laxiflora (Siebold \& Zucc.) Blume & Hornbeam & Leaf \\
\hline Carpinus laxiflora (Siebold \& Zucc.) Blume & Hornbeam & Stem, bark \\
\hline Carpinus tschonoskii Maxim. & Silky hornbeam & Stem, bark \\
\hline Castanopsis cuspidata var. sieboldii (Makino) Nakai & Japanese chinquapin & Stem, heart wood \\
\hline Celtis choseniana Nakai & Hackberry & Stem \\
\hline Cephalotaxus koreana Nakai & Korean plum yew & Leaf \\
\hline Chaenomeles lagenaria (Loisel.) Koidz. & Flowering quince & Stem \\
\hline Cinnamomum camphora(L.) J.Presl & Camphor laurel & Leaf \\
\hline Citrus dachibana (Makino) Tanaka. & Tachibana orange & Stem, bark \\
\hline Cleyera japonica Thunb. & Sakaki & Leaf \\
\hline Cornus controversa Hemsl. & Giant dogwood & Stem \\
\hline Corydalis incisa Pers. & Fumewort & Aerial parts \\
\hline Corylus heterophylla var. thunbergii Blume & Siberian filbert & Leaf, stem \\
\hline Crataegus pinnatifida Bunge & Mountain hawthorn & Stem \\
\hline Daphne genkwa Siebold \& Zucc. & Lilac Daphne & Stem, root \\
\hline Dioscorea tokoro Makino & Unknown & Rhizome [E] \\
\hline Dolichos lablab L. & Hyacinth bean & Seed $[E]$ \\
\hline Elaeagnus glabra Thunb. & Goat nipple & Stem \\
\hline Elaeagnus umbellate C.P.Thunb. ex A.Murray & Autumn olive & Leaf, stem \\
\hline Equisetum arvense $\mathrm{L}$. & Horsetail & Aerial parts [E] \\
\hline Erigeron annuus (L.) Pers. & Annual fleabane & Aerial parts \\
\hline Eriobotrya japonica (Thunb.) Lindl. & Japanese medlar & Leaf \\
\hline Euphorbia helioscopia L. & Sun spurge & Aerial parts \\
\hline Euphorbia sieboldiana C.Morren \& Decne. & Unknown & Aerial parts \\
\hline Eurya emarginata (Thunb.) Makino & Shore eurya & Leaf \\
\hline Ficus erecta Thunb. & Japanese fig & Fruit \\
\hline Ficus nipponica Franch. \& Sav. & Japanese fig & Stem \\
\hline Forsythia nakaii(Uyeki) T.B.Lee & Unknown & Stem \\
\hline Ginkgo biloba L. & Common gingko & Stem \\
\hline Hedera rhombea(Miq.) Siebold ex Bean & Japanese ivy & Leaf \\
\hline Hedera rhombea(Miq.) Siebold ex Bean & Japanese ivy & Fruit \\
\hline Hedera rhombea(Miq.) Siebold ex Bean & Japanese ivy & Aerial parts \\
\hline Hedera rhombea(Miq.) Siebold ex Bean & Japanese ivy & Stem \\
\hline Hepatica insularis Nakai & Unknown & Aerial parts \\
\hline $\begin{array}{l}\text { Heracleum moellendorffii f. Subbipinnatum (Franch.) } \\
\text { Kitag. }\end{array}$ & Cow parsnip & Leaf \\
\hline $\begin{array}{c}\text { Hydrangea serrata f. acuminate (Siebold \& Zucc.) } \\
\text { E.H.Wilson }\end{array}$ & Mountain hydrangea & Stem \\
\hline $\begin{array}{c}\text { Hydrangea serrata f. acuminate (Siebold \& Zucc.) } \\
\text { E.H.Wilson }\end{array}$ & Mountain hydrangea & Leaf, stem \\
\hline Ilex cornuta Lindl. \& Paxton & Chinese holly & Leaf \\
\hline Ilex crenata var. microphylla Maxim. & Japanese holly & Stem \\
\hline Illicium religiosum Siebold \& Zucc. & Japanese star anise & Stem \\
\hline Juniperus rigida Pav. ex Carrière & Needle juniper & Leaf \\
\hline Juniperus rigida Pav. ex Carrière & Needle juniper & Stem \\
\hline Kirengeshoma koreana Nakai & Yellow waxbells & Stem \\
\hline Kirengeshoma koreana Nakai & Yellow waxbells & Root \\
\hline Koelreuteria paniculata Laxm. & Golden raintree & Stem \\
\hline Lathyrus japonicas Willd. & Beach pea & Aerial parts \\
\hline Ligularia fischeri (Ledeb.) Turcz. & Fischers ragwort & Aerial parts \\
\hline
\end{tabular}


Table 1. Cont.

\begin{tabular}{|c|c|c|}
\hline Scientific Names & Common Names & Parts Used $^{1}$ \\
\hline Lindera erythrocarpa Makino & Asian spicebush & Stem \\
\hline Lindera obtusiloba Blume & Japanese spicebush & Leaf, stem \\
\hline Litsea japonica Mirb. & Unknown & Leaf \\
\hline Lonicera japonica Thunb. & Chinese honeysuckle & Leaf \\
\hline Lonicera japonica Thunb. & Chinese honeysuckle & Stem \\
\hline Lonicera vesicaria Kom. & Korean honeysuckle & Leaf, stem \\
\hline Lotus corniculatus var. japonicus Regel & Bird's foot trefoil & Aerial parts \\
\hline Luzula capitate (Miq. ex Franch. \& Sav.) Kom. & Sweep's woodbrush & Aerial parts \\
\hline Lycoris squamigera Maxim. & Magic-lily & Leaf \\
\hline Lycoris squamigera Maxim. & Magic-lily & Stem \\
\hline Machilus japonica Siebold \& Zucc. & Unknown & Twig \\
\hline Meehania urticifolia (Miq.) Makino & Japanese dead nettle & Aerial parts \\
\hline Megaleranthis saniculifolia Ohwi & Unknown & Aerial parts \\
\hline Melia azedarach var. japonica (G.Don) Mak. & Bead tree & Aerial parts \\
\hline Morus bombycis Koidz. & Korean mulberry & Leaf \\
\hline Orostachys iwarenge (Makino) Hara & Chinese Dunce cap & Aerial parts \\
\hline Osmanthus insularis Koidz. & Holly olive & Leaf \\
\hline Pharbitis nil (L.) Choisy & Japanese morning glory & Seed $[E]$ \\
\hline Pinus parviflora Siebold \& Zucc. & Japanese white pine & Leaf \\
\hline Pinus thunbergii Parl. & Japanese black pine & Leaf \\
\hline Pittosporum tobira (Murray) Aiton fil. & Japanese mock orange & Stem \\
\hline Potentilla fruticosa $\mathrm{L}$. & Shrubby cinquefoil & Stem \\
\hline Pourthiaea villosa (Thunb.) Decne. & Oriental Photinia & Stem \\
\hline Prunus sargentii Rehder & Sargent's cherry & Stem \\
\hline Pyrus calleryana var. fauriei (C.K.Schneid.) Rehder & Fauriei callery pear & Stem \\
\hline Quercus acuta Siebold ex Blume & Japanese evergreen oak & Stem \\
\hline Quercus aliena Blume & Oriental white oak & Leaf, stem \\
\hline Quercus gilva Blume & Redbark oak & Leaf \\
\hline Quercus gilva Blume & Redbark oak & Stem, heart wood \\
\hline Reynoutria sachalinensis (F.Schmidt) Nakai & Sakhalin knotweed & Fruit \\
\hline Rhodotypos scandens (Thunb.) Makino & Black jetbead & Stem \\
\hline Rhus trichocarpa Miq. & Bristly-fruit lacquer tree & Stem \\
\hline Rosa multiflora Murray & Many-flowered Rose & Leaf, stem \\
\hline Salix glandulosa Seemen & Korean king Willow & Stem \\
\hline Salix hulteni Flod. & Hulten Willow & Stem \\
\hline Sambucus sieboldiana var. pendula (Nakai) T.B.Lee & Japanese red elder & Stem \\
\hline Saussurea lappa(Decne.) C.B.Clarke, 1876 & Indian costus & Root $[E]$ \\
\hline Sinapis alba L. & White mustard & Seed $[E]$ \\
\hline Sorbus alnifolia (Sieb. \& Zucc.) C.Koch & Korean mountain ash & Stem \\
\hline Spiraea salicifolia $\mathrm{L}$. & Bridewort & Stem \\
\hline Spirodela polyrhiza (L.) Schleid. & Common duckmeat & Aerial parts [E] \\
\hline Staphylea bumalda DC. & Bumalda bladdernut & Stem \\
\hline Strychnos nux-vomica L. & Nux-vomica & Seed $[E]$ \\
\hline Styrax obassia Siebold \& Zucc. & Fragrant snowbell & Stem \\
\hline Taxus cuspidate Siebold \& Zucc. & Japanese yew & Stem \\
\hline Thea sinensis $\mathrm{L}$. & Chinese tea & Leaf \\
\hline Torreya nucifera Siebold \& Zucc. & Japanese nutmeg tree & Stem \\
\hline Trachelospermum asiaticum var. intermedium Nakai & Chinese jasmine & Leaf \\
\hline Trachelospermum jasminoides (Lindl.) Lem. & Star jasmine & Stem, leaf $[\mathrm{E}]$ \\
\hline Tribulus terrestris $\mathrm{L}$. & Puncture vine & Leaf $[E]$ \\
\hline Tribulus terrestris L. & Puncture vine & Seed $[E]$ \\
\hline Triticum aestivum $\mathrm{L}$. & Common wheat & Seed $[E]$ \\
\hline
\end{tabular}


Table 1. Cont.

\begin{tabular}{ccc}
\hline Scientific Names & Common Names & Parts Used ${ }^{\mathbf{1}}$ \\
\hline Tsuga sieboldii Carrière & Japanese hemlock & Leaf \\
Vaccinium bracteatum Thunb. & Sea bilberry & Leaf \\
Viburnum awabuki Hort.Berol. ex C.Koch & Sweet viburnum & Leaf \\
Viburnum carlesii Hemsl. ex Forb. \& Hemsl. & Korean spice viburnum & Stem \\
Viburnum sargentii Koehne & Sargent viburnum & Stem \\
Vicia angustifolia var. segetalis (Thuill.) W.D.J.Koch & Black-pod vetch & Aerial parts \\
Viola japonica Langsd. ex DC. & Japanese violet & Aerial parts \\
Viola tokubuchiana var. takedana (Makino) Maek. & Unknown & Aerial parts \\
Vitex negundo var. incisa (Lam.) C.B.Clarke & Chinese chaste tree & Stem \\
Vitis coignetiae Pulliat ex Planch. & Crimson gloryvine & Stem \\
Youngia denticulata (Houtt.) Kitam. & Unknown & Aerial parts \\
\hline
\end{tabular}

${ }^{1}$ Unless indicated otherwise, methanol (95\%) was used for extraction. [E], ethanol (95\%) used for extraction.

\subsection{In Vitro Rumen Fermentation Assay}

Two cannulated Holstein steers (mean body weight $680 \pm 30 \mathrm{~kg}$ ), cared for in accordance with the guidelines of the Animal Ethical Committee, Seoul National University, Republic of Korea (approval number SNU-160105-1), were used as rumen fluid donors. The animals were fed twice daily with $3.5 \mathrm{~kg}$ rice straw containing $\left(\mathrm{k}^{-1}\right.$ dry matter [DM]) $857 \mathrm{~g}$ organic matter; $48 \mathrm{~g}$ crude protein; $26 \mathrm{~g}$ ether extract; $768 \mathrm{~g}$ neutral detergent fibre; $417 \mathrm{~g}$ acid detergent fibre; and $2.0 \mathrm{~kg}$ of commercial concentrate with $\left(\mathrm{k}^{-1} \mathrm{DM}\right) 896 \mathrm{~g}$ organic matter, $156 \mathrm{~g}$ crude protein, $53 \mathrm{~g}$ ether extract, $310 \mathrm{~g}$ neutral detergent fibre, and $122 \mathrm{~g}$ acid detergent fibre. Ruminal digesta of approximately $800 \mathrm{~mL}$ was collected from each steer before the morning feeding and strained through four layers of muslin into a pre-warmed flask flushed with $\mathrm{O}_{2}$-free $\mathrm{CO}_{2}$. The fluid was diluted with $\mathrm{O}_{2}$-free buffer (adjusted to $\mathrm{pH}$ 7.0) [26] at a ratio of $1: 2(v / v)$ and placed in a water bath pre-heated to $39^{\circ} \mathrm{C}$ with continuous $\mathrm{CO}_{2}$ flushing. Briefly, an in vitro screening assay was performed by incubating $20 \mathrm{mg}$ of the extracts (dissolved in $1 \mathrm{~mL}$ of $10 \%$ dimethyl sulphoxide) with $30 \mathrm{~mL}$ of mixed rumen microorganisms in $60-\mathrm{mL}$ serum bottles containing $200 \mathrm{mg}$ DM of total mixed ration as the substrate. The ingredient and nutrient compositions of the substrate are provided in Table 2. The in vitro screening trial of all 152 plant extracts were tested in 2 different cycles with approximately 9-10 extracts per fermentation run with a total of 8 runs per cycle. Each run contained a control (i.e., with substrate and without plant extract), treatment (i.e., with substrate and $20 \mathrm{mg}$ of plant extract), positive control (i.e., with substrate and $30 \mathrm{ppm}$ of monensin; CAS No. 22373-78-0, Sigma-Aldrich, St. Louis, MO, USA), and three replicates. The bottles were sealed with rubber stoppers, covered with aluminium, and incubated at $39^{\circ} \mathrm{C}$ for $24 \mathrm{~h}$. After the completion of eight fermentation run (one cycle), potential candidates were chosen based on their abilities to decrease $\mathrm{CH}_{4}$ production by more than $20 \%$, compared to their respective controls [21]. The same experimental procedure was followed for the screening assay in the second cycle. In vitro confirmation incubations using the selected potential candidates from each cycle of the screening test were performed to validate the results. In this assay, there were four replications of the control, monensin, and each candidate at a lower dosage of $10 \mathrm{mg}$. The fermentation run was repeated on three different days to check consistency. 
Table 2. Ingredients and chemical composition of substrate used in the in vitro screening and confirmation assays.

\begin{tabular}{cc}
\hline Ingredient Composition & g/kg DM \\
\hline Timothy hay & 46 \\
Klein grass & 31 \\
Oat hay & 31 \\
Alfalfa hay & 73 \\
Tall fescue grass & 69 \\
Rye grass & 38 \\
Cotton seed & 43 \\
Beet pulp & 77 \\
Corn gluten feed & 136 \\
Dried brewers' grains & 195 \\
Commercial concentrate & 230 \\
Vitamin-Mineral premix ${ }^{1}$ & 23 \\
Probiotics & 9 \\
\hline Chemical Composition & g/kg DM \\
\hline Organic matter & 910 \\
Crude protein & 143 \\
Ether extract & 38 \\
Neutral detergent fibre ${ }^{2}$ & 289 \\
Acid detergent fibre ${ }^{3}$ & 143 \\
Gross energy, MJ/kg DM & 17.7
\end{tabular}

${ }^{1}$ Provided following nutrients per kg of mixture (Grobic-DC, Bayer Health Care, Leverkusen, Germany): Vit. A, 2,650,000 IU; Vit. D3, 530,000 IU; Vit. E, 1050 IU; Niacin, 10,000 mg; Mn, 4400 mg; Zn, 4400 mg; Fe, 13,200 mg; $\mathrm{Cu}, 2200 \mathrm{mg} ; \mathrm{I}, 440 \mathrm{mg} ; \mathrm{Co}_{1} 440 \mathrm{mg} .{ }^{2}$ Neutral detergent fibre assayed with a heat stable amylase and expressed exclusive of residual ash. ${ }^{3}$ Acid detergent fibre expressed excluding residual ash

\subsection{Measurements and Chemical Analysis}

After $24 \mathrm{~h}$ of incubation, the total gas volume in the headspace of the bottle was measured using a water displacement apparatus [27]. A gas sample was transferred to a 10-mL vacuum tube (ref 364979, BD Vacutainer, Becton Dickinson, Franklin Lakes, NJ, USA) for $\mathrm{CH}_{4}$ analysis. Then, the bottles were placed on ice to stop fermentation, the incubation medium was transferred to a $50-\mathrm{mL}$ beaker, and the $\mathrm{pH}$ was measured using a $\mathrm{pH}$ meter (model AG 8603; Seven Easy pH, Mettler-Toledo, Schwerzenbach, Switzerland). For the microbial analysis, a $10-\mathrm{mL}$ sample of incubation medium was stored at $-80^{\circ} \mathrm{C}$ until DNA was extracted. The remaining medium was centrifuged at $12,000 \times \mathrm{g}$ for $10 \mathrm{~min}$ (Centrifuge Smart 15, Hanil Science Industrial, Seoul, Korea), and the supernatant was stored at $-20^{\circ} \mathrm{C}$ to determine the ammonia nitrogen $\left(\mathrm{NH}_{3}-\mathrm{N}\right)$ and volatile fatty acid (VFA) concentrations.

$\mathrm{CH}_{4}$ concentration in the headspace gas was determined using the Agilent 7890B GC system (Agilent Technologies, Santa Clara, CA, USA) with a flame ionization detector. The inlet and detector temperature were maintained at $200^{\circ} \mathrm{C}$ and $250{ }^{\circ} \mathrm{C}$, respectively. A 10-mL sample was injected through the back inlet using a 10-mL graduated syringe connected to a two-way stopcock (KOVAX, Seoul, Korea) with a split ratio of 10:1 into a $30 \mathrm{~m} \times 0.53 \mathrm{~mm} \times 20 \mu \mathrm{m}$ HayeSep Q-ValcoPLOT fused-silica capillary column (CFSPQ3053-200, VICI Metronics, Danvers, MA, USA). The carrier gas helium (99.99\%; Air Korea) was set to a flow rate of $10 \mathrm{~mL} / \mathrm{min}$ and the oven temperature of $80{ }^{\circ} \mathrm{C}$ was held constant for $2.5 \mathrm{~min}$. $\mathrm{CH}_{4}$ content was calculated by external calibration, using a certified gas mixture $\left(8 \% \mathrm{~mol} / \mathrm{mol}\right.$ balance $\mathrm{N}_{2}$; Air Korea). The $\mathrm{NH}_{3}-\mathrm{N}$ concentration was determined using a modified colorimetric method [28]. For VFA analysis, 5.0-mL aliquot of sample was mixed with $1.0 \mathrm{~mL} 25 \% \mathrm{HPO}_{3}$ and $0.2 \mathrm{~mL} 2 \%$ pivalic acid [29], then analysed using gas chromatography as described previously to identify the VFAs [30]. The feed and substrate samples were dried in a forced-air oven at $65^{\circ} \mathrm{C}$ for $72 \mathrm{~h}$ to estimate DM content and then ground to pass through a 1-mm screen (Model 4, Thomas Scientific, Swedesboro, NJ, USA). Nutrient compositions were determined using methods described previously [30]. 


\subsection{Analysis of Plant Secondary Metabolites}

Total phenols, total tannins, and condensed tannins were determined in the selected crude extracts based on the method described by Makkar [31]. For extraction, $60 \mathrm{mg}$ of crude methanol or ethanol extract was mixed with $3.5 \mathrm{~mL}$ of aqueous acetone $(70: 30 \mathrm{v} / \mathrm{v})$, vortexed, and incubated at room temperature for $1 \mathrm{~h}$. Subsequently, the mixture was centrifuged at $3000 \times g$ (Hanil Science Industrial, Gimpo, Korea) for $10 \mathrm{~min}$, and the supernatant was collected and used for assays. Total phenols and total tannins were expressed as catechin (CAS No. 225937-10-0, Sigma-Aldrich) equivalents and condensed tannins were expressed as cyanidin (CAS No.528-58-5, Sigma-Aldrich) equivalents. Total tannic acids or hydrolysable tannins (HTs) were estimated as the difference between total tannins and condensed tannins [32]. Total saponin (TS) content was determined [33], and expressed as escin (CAS No. 6805-41-0, Sigma-Aldrich) equivalents. PSMs were expressed as units per milligram of extract, because the DM contents of the plant parts and extraction yield were unknown.

\subsection{Gas Chromatography-Mass Spectrometry (GC-MS) Analysis}

Seeds of Pharbitis nil (100 g) were ground and extracted with $1000 \mathrm{~mL}$ of ethanol (98\%) for $24 \mathrm{~h}$ at room temperature in an orbital shaker. The extract was filtered through Whatman No. 2 filter paper and concentrated using a rotary vacuum evaporator (Heidolph Instruments, Schawabatch, Germany). The resulting extract (without derivatization) was diluted 10-fold, and the GC-MS analysis was performed using a TSQ 8000 triple quadrupole MS interfaced with a TRACE 1310 GC (Thermo Scientific, Waltham, MA, USA) equipped with a TG-5MS $(30 \times 0.25 \mathrm{~mm} \times 0.25 \mu \mathrm{m}$; Agilent Technologies) $5 \%$-phenyl-methylpolysiloxane fused capillary column. Pure helium gas (99.99\%; Air Korea) was used as the carrier gas at a constant flow rate of $1.2 \mathrm{~mL} / \mathrm{min}$ and a splitless injection volume of $1 \mu \mathrm{L}$. The injector temperature was maintained at $280^{\circ} \mathrm{C}$ and oven temperature was programmed from $80^{\circ} \mathrm{C}$ (isothermal for $2 \mathrm{~min}$ ), with an increase of $15^{\circ} \mathrm{C} / \mathrm{min}$ to $250^{\circ} \mathrm{C}$ (isothermal for $5 \mathrm{~min}$ ), then $15{ }^{\circ} \mathrm{C} / \mathrm{min}$ to $300{ }^{\circ} \mathrm{C}$, ending with a 4 -min isothermal incubation at $300{ }^{\circ} \mathrm{C}$. Mass spectra were collected at $70 \mathrm{eV}$ with a scan-interval of $1.0 \mathrm{~s}$ and fragments ranging from 50 to $550 \mathrm{~m} / \mathrm{z}$. The solvent delay was 0 to $2 \mathrm{~min}$, and total run time was $25 \mathrm{~min}$. Phytochemicals present in the extracts were identified based on a comparison of their mass spectral patterns with the spectral database at the library of the National Institute of Standards and Technology (NIST, Gaithersburg, MD, USA).

\subsection{DNA Extraction and Real-Time PCR}

Genomic DNA from the incubation medium was extracted using the NucleoSpin soil kit (Macherey-Nagel, DuĖren, Germany), and nucleic acid concentrations were measured as described previously [30]. The integrity of the gDNA was confirmed by visualising the bands using eco dye-stained (Biofact, Seoul, Korea) agarose gel electrophoresis. Real-time PCR assays to determine the relative abundances of major cellulolytic bacteria, such as Ruminococcus albus, Ruminococcus flavefaciens, Fibrobacter succinogens, total methanogens, and ciliated protozoa were performed using the SYBR Green real-time-PCR Master Mix (Bioneer, Daejeon, Korea) and the CFX96 Touch ${ }^{\mathrm{TM}}$ Real-Time PCR Detection System (BioRad Laboratories Inc., Hercules, CA, USA). Thermal cycling was performed based on the annealing temperature that showed high product band intensity and determined by multiple gradient PCR for each primer set as shown in Table 3. The primers targeted the $16 \mathrm{~s}$ or $18 \mathrm{~s}$ variable region for relative quantification. Briefly, the PCR was carried out in $20-\mu \mathrm{L}$ total reaction volumes containing $20 \mathrm{ng}$ gDNA, $10 \mu \mathrm{L}$ SYBR Green RT-PCR Master Mix, and $1.0 \mu \mathrm{L}$ of each $10-\mu \mathrm{M}$ primer. Thermal cycling consisted of initial denaturation at $95^{\circ} \mathrm{C}$ for $10 \mathrm{~min}$, followed by 40 cycles at $94{ }^{\circ} \mathrm{C}$ for $15 \mathrm{~s}$ and annealing for $30 \mathrm{~s}$ followed by extension at $72{ }^{\circ} \mathrm{C}$ for $30 \mathrm{~s}$ [34]. The annealing was carried out at specific temperatures corresponded for each primer sets as mentioned in Table 3. After an amplification cycle, a melting curve analysis was performed starting at $65^{\circ} \mathrm{C}$ with an increase of $0.5^{\circ} \mathrm{C}$ to 
$95^{\circ} \mathrm{C}$, followed by a plate read. The $2^{-\Delta \Delta \mathrm{CT}}$ method was used to determine the relative fold-changes [35], and all data were normalised to the abundance of total bacteria.

Table 3. Oligonucleotide primers used for real-time PCR assay.

\begin{tabular}{|c|c|c|c|c|}
\hline Target Group & Primer Sequence & $\mathrm{T}_{\mathrm{m}}\left({ }^{\circ} \mathrm{C}\right)$ & Size (bp) & Reference \\
\hline Total bacteria & $\begin{array}{c}\text { F: CGG CAA CGA GCG CAA CCC } \\
\text { R: CCA TTG TAG CAC GTG TGT AGC C }\end{array}$ & 60.5 & 130 & [36] \\
\hline Fibrobacter succinogenes & $\begin{array}{l}\text { F: GTT CGG AAT TAC TGG GCG TAA A } \\
\text { R: CGC CTG CCC CTG AAC TAT C }\end{array}$ & 51.7 & 120 & [36] \\
\hline Ruminococcus albus & $\begin{array}{l}\text { F: CCC TAA AAG CAG TCT TAG TTC G } \\
\text { R: CCT CCT TGC GGT TAG AAC A }\end{array}$ & 47.0 & 176 & [37] \\
\hline Ruminococcus flavefaciens & $\begin{array}{l}\text { F: CGA ACG GAG ATA ATT TGA GTT TAC TTA GG } \\
\text { R: CGG TCT CTG TAT GTT ATG AGG TAT TAC C }\end{array}$ & 53.3 & 132 & [36] \\
\hline Total methanogens & $\begin{array}{l}\text { F: CCGGAGATGGAACCTGAGAC } \\
\text { R: CGGTCTTGCCCAGCTCTTATTC }\end{array}$ & 52.6 & 165 & [38] \\
\hline Ciliate protozoa & $\begin{array}{c}\text { F: GAG CTA ATA CAT GCT AAG GC } \\
\text { R: CCC TCA CTA CAA TCG AGA TTT AAG G }\end{array}$ & 46.2 & 180 & [34] \\
\hline
\end{tabular}

\subsection{Statistical Analysis}

In screening assay, Student's t-test was used to compare the total gas and $\mathrm{CH}_{4}$ production levels in the control bottles with those levels in bottles containing a given plant additive from the same incubation run. The effects were expressed as relative change to the value of the control for the specific incubation run. The confirmation assay results were analysed using one-way analysis of variance, followed by Newman-Keuls multiple comparison tests. All statistical analyses were performed using GraphPad Prism, version 5.0 (GraphPad Software Inc., La Jolla, CA, USA), and a $p$-value $<0.05$ was considered statistically significant. To identify bacterial lineages and other parameters that differentiated the control and treatment groups, we performed principal component analysis using the fviz_pca_biplot function in the FactoMineR [39] package of R-software, version 4.0.3 (The $\mathrm{R}$ Foundation for Statistical Computing, Vienna, Austria). The non-parametric Kendall rank-correlation coefficient was calculated to identify correlations among $\mathrm{CH}_{4}$ production, fermentation characteristics, bacterial communities, and PSMs using the PROC CORR function in SAS software, version 9.4 (SAS Institute, Cary, NC, USA).

\section{Results and Discussion}

While many strategies have been proposed to mitigate enteric $\mathrm{CH}_{4}[2,3]$, most (e.g., defaunation, direct-fed microbials, ionophores, and bacteriocins) are difficult to implement at the farm level due to practical difficulties. Therefore, dietary manipulations, such as plant-based anti-methanogenic feed additives, offer highly effective $\mathrm{CH}_{4}$ mitigation approaches [4,13-16,19,40-42]. In vitro experimental models are very useful for the preliminary screening of a large number of plant additives to select a few potent additives with desired characteristics. Plants are either directly used in the reaction mixture [20-22] or used as dry extracts during the screening process [23]. Therefore, we initially obtained 152 dry methanolic or ethanolic extracts of 137 plant species that are widely distributed in Korea and could be readily available as potential feed additives.

The relative effects of each plant extract on total gas and $\mathrm{CH}_{4}$ production (mmol per $\mathrm{g}$ of DM) during a screening assay conducted during the two different cycles are shown in Figure 1. $\mathrm{CH}_{4}$ production decreased by more than $10 \%$ in $20 \%$ of the extracts tested. Although the extracts from stems of Acer tegmentosum Maxim., leaves of Carpinus laxiflora (Siebold \& Zucc.) Blume, leaves of Cleyera japonica Thunb., aerial parts of Erigeron annuus Pers., stems of Taxus cuspidate Siebold \& Zucc., and stems of Ginkgo biloba L. exhibited a reduction of $\mathrm{CH}_{4}$ close to $20 \%$, they were not included as candidates for the confirmation 
assay. Only eight extracts ( $5 \%$ of the extracts tested) reduced $(p<0.1) \mathrm{CH}_{4}$ production by more than 20\% (Supplementary Table S1) and were considered promising candidates for subsequent confirmation assays. These included stems of Vitex negundo var. incisa (Lam.) C.B. Clarke (VI), stems of Amelanchier asiatica (Siebold \& Zucc.) Endl. ex Walp. (AM), fruit of Reynoutria sachalinensis Nakai (RE) from cycle 1, seeds of Tribulus terrestris L. (TR), seeds of Pharbitis nil (L.) Choisy (PA), leaves of Alnus japonica Siebold \& Zucc. (AL), stems and bark of Carpinus tschonoskii Maxim. (CA), and stems of Acer truncatum Bunge (AC) from cycle 2. Among these, PA exhibited the maximum reduction of $\mathrm{CH}_{4}$ by $63 \%$, compared to the control. Most potential plant extracts decreased $(p<0.1)$ total gas production by $12-35 \%$, except VI and TR, which had a negligible effect (Supplementary Table S1). These results could be attributed to the dosage $(20 \mathrm{mg})$ of the plant extracts, which may have had a detrimental effect on ruminal microbes. Thus, the plant extracts were tested at a relatively lower dosage $(10 \mathrm{mg})$ in subsequent confirmation assays, compared to the dosage in screening assays.

Cycle 1

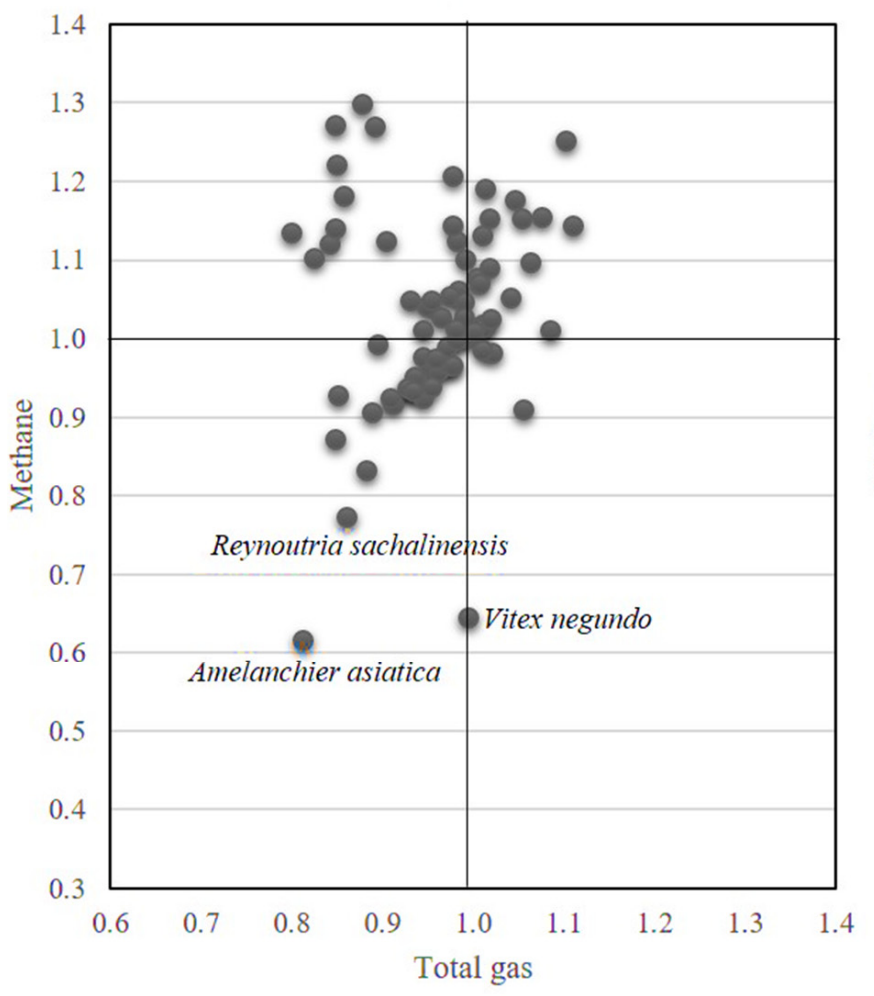

Cycle 2

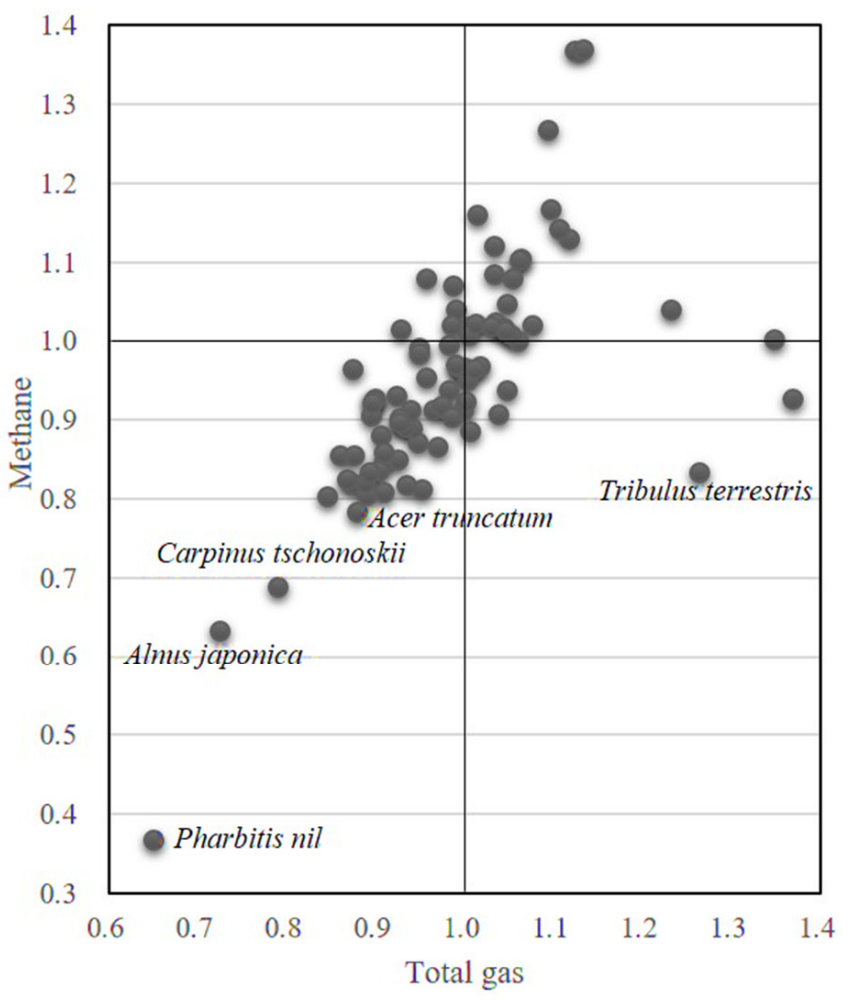

Figure 1. Relative changes in total gas production and $\mathrm{CH}_{4}$ concentration in gas, respective to their controls, after 24-h in vitro incubation with plant extracts (replicate $=3$ ). Control is considered as 1 .

The effects of the selected candidates on $\mathrm{CH}_{4}$, gas production, fermentation characteristics, and microbial abundance were confirmed in an in vitro assay (Tables 4 and 5). Significant decreases $(p<0.05)$ in $\mathrm{CH}_{4}$ production (mmol per $\mathrm{g}$ of DM incubated) in response to adding VI (17\%), AM (17\%), RE (19\%), TR (22\%), PA (37\%), AL (27\%), AC (23\%), and CA $(23 \%)$ were observed at half extract concentrations, compared to the screening assay. This also corresponded to reductions of $\mathrm{CH}_{4}$ concentration in total gas of $7 \%, 11 \%$, $9 \%, 9 \%, 15 \%, 11 \%, 10 \%$, and $10 \%(p<0.05)$, respectively, compared to the control. 
Table 4. Effects of selected plant extracts from cycle 1 on $\mathrm{CH}_{4}$ production, rumen fermentation parameters, and microbial abundance after 24 -h in vitro incubation (replicate $=4$ )

\begin{tabular}{|c|c|c|c|c|c|c|c|}
\hline Item & Control & Monensin & $\begin{array}{c}\text { Vitex } \\
\text { negundo }\end{array}$ & $\begin{array}{c}\text { Amelanchier } \\
\text { asiatica }\end{array}$ & $\begin{array}{c}\text { Reynoutria } \\
\text { sachalinensis }\end{array}$ & SEM & $p$-Value \\
\hline $\mathrm{pH}$ & $6.0^{b}$ & $6.4^{\mathrm{a}}$ & $6.4^{\mathrm{a}}$ & $6.4^{\mathrm{a}}$ & $6.4^{\mathrm{a}}$ & 0.04 & $<0.001$ \\
\hline $\begin{array}{l}\text { Gas, } \mathrm{mmol} / \mathrm{g} \mathrm{DM} \\
\text { substrate }\end{array}$ & 11.2 & 9.3 & 10.01 & 10.3 & 9.9 & 0.49 & 0.158 \\
\hline $\begin{array}{l}\mathrm{CH}_{4}, \mathrm{mmol} / \mathrm{g} \mathrm{DM} \\
\text { substrate }\end{array}$ & $1.5^{\mathrm{a}}$ & $1.1^{\mathrm{b}}$ & $1.3^{\mathrm{b}}$ & $1.2^{b}$ & $1.2^{b}$ & 0.07 & 0.018 \\
\hline $\mathrm{CH}_{4}, \mathrm{mmol} / \mathrm{mol}$ gas & $134.1^{\mathrm{a}}$ & $121.3^{b}$ & $124.6^{\mathrm{b}}$ & $119.9^{b}$ & $121.9^{b}$ & 1.94 & 0.001 \\
\hline Total VFAs, mM & $166.0^{a}$ & $126.8^{b}$ & $127.6^{\mathrm{b}}$ & $127.1^{\mathrm{b}}$ & $127.7^{\mathrm{b}}$ & 6.83 & 0.003 \\
\hline Acetate $\left(C_{2}\right), \%$ & 57.3 & 57.5 & 58.4 & 58.3 & 58.4 & 1.74 & 0.987 \\
\hline Propionate $\left(\mathrm{C}_{3}\right), \%$ & 24.8 & 25.8 & 25.0 & 25.1 & 25.0 & 1.10 & 0.999 \\
\hline Isobutyrate, $\%$ & 1.0 & 1.0 & 1.0 & 1.0 & 1.0 & 0.03 & 0.980 \\
\hline Butyrate, $\%$ & 12.2 & 11.1 & 11.2 & 11.3 & 11.2 & 1.20 & 0.965 \\
\hline Isovalerate, $\%$ & 2.8 & 2.8 & 2.6 & 2.6 & 2.6 & 0.27 & 0.967 \\
\hline Valerate, $\%$ & 2.0 & 1.9 & 1.9 & 1.8 & 1.8 & 0.23 & 0.981 \\
\hline $\mathrm{C}_{2} / \mathrm{C}_{3}$ & 2.3 & 2.2 & 2.3 & 2.3 & 2.3 & 0.09 & 0.933 \\
\hline $\mathrm{NH}_{3}-\mathrm{N}, \mathrm{mg} / \mathrm{dL}$ & $28.5^{\mathrm{a}}$ & $20.9^{b}$ & $19.9^{b}$ & $19.7^{b}$ & $19.4^{\mathrm{b}}$ & 2.00 & 0.027 \\
\hline \multicolumn{8}{|l|}{ Expression fold change } \\
\hline R. flavefaciens & $1.0^{\mathrm{d}}$ & $6.8^{\mathrm{a}}$ & $3.6^{c}$ & $2.7^{\mathrm{c}}$ & $5.2^{b}$ & 0.53 & $<0.001$ \\
\hline R. albus & $1.0^{\mathrm{d}}$ & $5.4^{\mathrm{c}}$ & $2.4^{\mathrm{d}}$ & $6.0^{\mathrm{cb}}$ & $12.7^{\mathrm{a}}$ & 1.17 & $<0.001$ \\
\hline F. succinogenes & $1.0^{\mathrm{c}}$ & $0.9^{\mathrm{cd}}$ & $2.4^{\mathrm{a}}$ & $2.3^{\mathrm{ab}}$ & $1.0^{\mathrm{cd}}$ & 0.21 & $<0.001$ \\
\hline Total methanogens & $1.0^{\mathrm{a}}$ & $0.4^{b}$ & $0.3^{c}$ & $0.1^{\mathrm{d}}$ & $0.3^{\mathrm{c}}$ & 0.02 & $<0.001$ \\
\hline Ciliate protozoa & $1.0^{\mathrm{b}}$ & $0.3^{\mathrm{d}}$ & $0.7^{\mathrm{c}}$ & $1.3^{\mathrm{a}}$ & $0.3^{\mathrm{d}}$ & 0.13 & $<0.001$ \\
\hline
\end{tabular}

Means with different superscripts differ significantly $p<0.05$.

Principal component analysis also discriminated the treatments from their respective controls, explaining $57.6 \%$ and $47.8 \%$ of variation during cycles 1 and 2, respectively (Figure 2). Furthermore, this is the first study to report the anti-methanogenic activities of these extracts, although reports regarding such activities are available for leaves of VI [43], and gross saponins from TR [44]. However, the extents of $\mathrm{CH}_{4}$ mitigation in previous studies might not be comparable with the extent in the current study because of the different plant parts and dosages used. In addition, despite the lower dose of supplemented extracts compared to the screening assay, an increase $(p<0.05)$ in $\mathrm{pH}$ and decreases $(p<0.05)$ in total gas production, total VFA, and $\mathrm{NH}_{3}-\mathrm{N}$ were detected in the confirmation assay. A higher $\mathrm{pH}$ and reduced VFA concentrations are indications of overall inhibition of rumen microbial fermentation, which would not be nutritionally beneficial to the host animal, since VFAs are major energy source for the ruminants [45]. However, this effect is comparable with the effect of monensin, suggesting that the extracts have similar properties to those of monensin. This could be attributed to the greater concentrations of PSMs in the tested extracts, which are known for their anti-microbial activities [46]. Most of the plant extracts tested in this study (except seeds of TR and PA) were rich in total phenols, total tannins, HTs, and TSs (Table 6). This is consistent with previous studies reporting greater concentrations of polyphenols, flavonoids, and saponins in tested plant species with anti-microbial properties [47-52]. It has also been reported that HTs reduce the production of total VFAs through actions on ruminal microbes $[53,54]$. This is further supported by the significant decrease $(p<0.001)$ in the F. succinogens population in this experiment (Table 5), which is an efficient producer of succinate and the major precursor for propionate synthesis [55]. 
Table 5. Effects of selected plant extracts from cycle 2 on $\mathrm{CH}_{4}$ production, rumen fermentation parameters, and microbial abundance after 24 -h in vitro incubation (replicate $=4$ )

\begin{tabular}{|c|c|c|c|c|c|c|c|c|c|}
\hline Item & Control & Monensin & $\begin{array}{l}\text { Tribulus } \\
\text { terrestris }\end{array}$ & Pharbitis nil & Alnus japonica & Acer truncatum & $\begin{array}{c}\text { Carpinus } \\
\text { tschonoskii }\end{array}$ & SEM & $p$-Value \\
\hline $\mathrm{pH}$ & $6.1^{\mathrm{b}}$ & $6.5^{\mathrm{a}}$ & $6.4^{\mathrm{b}}$ & $6.4^{\mathrm{b}}$ & $6.4^{\mathrm{b}}$ & $6.4^{\mathrm{b}}$ & $6.4^{\mathrm{b}}$ & 0.05 & 0.001 \\
\hline Gas, mmol/g DM substrate & $12.7^{\mathrm{a}}$ & $10.4^{\mathrm{b}}$ & $10.6^{b}$ & $9.4^{b}$ & $10.5^{b}$ & $10.8^{b}$ & $10.6^{b}$ & 0.58 & 0.027 \\
\hline $\mathrm{CH}_{4}, \mathrm{mmol} / \mathrm{g}$ DM substrate & $1.8^{\mathrm{a}}$ & $1.3^{\mathrm{b}}$ & $1.4^{\mathrm{b}}$ & $1.2^{b}$ & $1.4^{\mathrm{b}}$ & $1.4^{\mathrm{b}}$ & $1.4^{\mathrm{b}}$ & 0.13 & 0.038 \\
\hline $\mathrm{CH}_{4}, \mathrm{mmol} / \mathrm{mol}$ gas & $144.8^{\mathrm{a}}$ & $127.3^{b}$ & $131.6^{\mathrm{b}}$ & $122.9^{b}$ & $128.7^{\mathrm{b}}$ & $130.7^{b}$ & $130.6^{b}$ & 2.93 & 0.037 \\
\hline Total VFAs, mM & $175.2^{\mathrm{a}}$ & $132.2^{b}$ & $134.5^{b}$ & $133.1^{\mathrm{b}}$ & $132.2^{b}$ & $130.7^{\mathrm{b}}$ & $133.7^{\mathrm{b}}$ & 9.84 & 0.044 \\
\hline Acetate $\left(C_{2}\right), \%$ & 55.3 & 54.4 & 56.3 & 53.0 & 56.4 & 56.4 & 56.5 & 3.47 & 0.988 \\
\hline Propionate $\left(C_{3}\right), \%$ & $21.1^{\mathrm{a}}$ & $23.3^{b}$ & $21.8^{\mathrm{ab}}$ & $27.1^{b}$ & $21.9^{a b}$ & $21.8^{\mathrm{ab}}$ & $21.8^{\mathrm{ab}}$ & 1.26 & 0.047 \\
\hline Isobutyrate, $\%$ & 1.4 & 1.4 & 1.3 & 1.1 & 1.3 & 1.3 & 1.3 & 0.11 & 0.646 \\
\hline Butyrate, $\%$ & 15.9 & 14.7 & 14.8 & 13.7 & 14.8 & 14.7 & 14.8 & 1.39 & 0.967 \\
\hline Isovalerate, $\%$ & 3.6 & 3.7 & 3.4 & 3.2 & 3.3 & 3.3 & 3.3 & 0.31 & 0.913 \\
\hline Valerate, $\%$ & $2.7^{\mathrm{a}}$ & $2.6^{\text {abef }}$ & $2.5^{\text {abcef }}$ & $1.8^{\mathrm{d}}$ & $2.4^{\mathrm{e}}$ & $2.4^{\mathrm{ef}}$ & $2.4^{\text {bcefg }}$ & 0.05 & $<0.001$ \\
\hline $\mathrm{C}_{2} / \mathrm{C}_{3}$ & 2.6 & 2.4 & 2.6 & 2.0 & 2.6 & 2.6 & 2.6 & 0.17 & 0.097 \\
\hline $\mathrm{NH}_{3}-\mathrm{N}, \mathrm{mg} / \mathrm{dL}$ & $42.9^{\mathrm{a}}$ & $34.2^{b}$ & $33.4^{b}$ & $32.2^{b}$ & $30.8^{b}$ & $29.9^{b}$ & $28.4^{b}$ & 2.20 & 0.003 \\
\hline \multicolumn{10}{|l|}{ Expression fold change } \\
\hline R. flavefaciens & $1.0^{\mathrm{g}}$ & $3.3^{\mathrm{e}}$ & $4.9^{\mathrm{d}}$ & $0.5^{\mathrm{f}}$ & $6.25^{c}$ & $7.5^{b}$ & $10.2^{\mathrm{ag}}$ & 0.76 & $<0.001$ \\
\hline R. albus & $1.0 \mathrm{~g}$ & $3.7^{\mathrm{dfg}}$ & $4.7^{\text {bcdefg }}$ & $4.1^{\text {bcdefg }}$ & $13.02^{\mathrm{a}}$ & $2.1^{\mathrm{fg}}$ & $2.7^{\text {defg }}$ & 0.94 & $<0.001$ \\
\hline Ciliate protozoa & $1.0^{\mathrm{c}}$ & $0.1^{\mathrm{d}}$ & $16.9^{\mathrm{a}}$ & $0.1^{\mathrm{d}}$ & $12.2^{b}$ & $2.8^{\mathrm{cd}}$ & $6.1^{\mathrm{c}}$ & 1.56 & $<0.001$ \\
\hline
\end{tabular}

Means with different superscripts differ significantly $p<0.05$. 

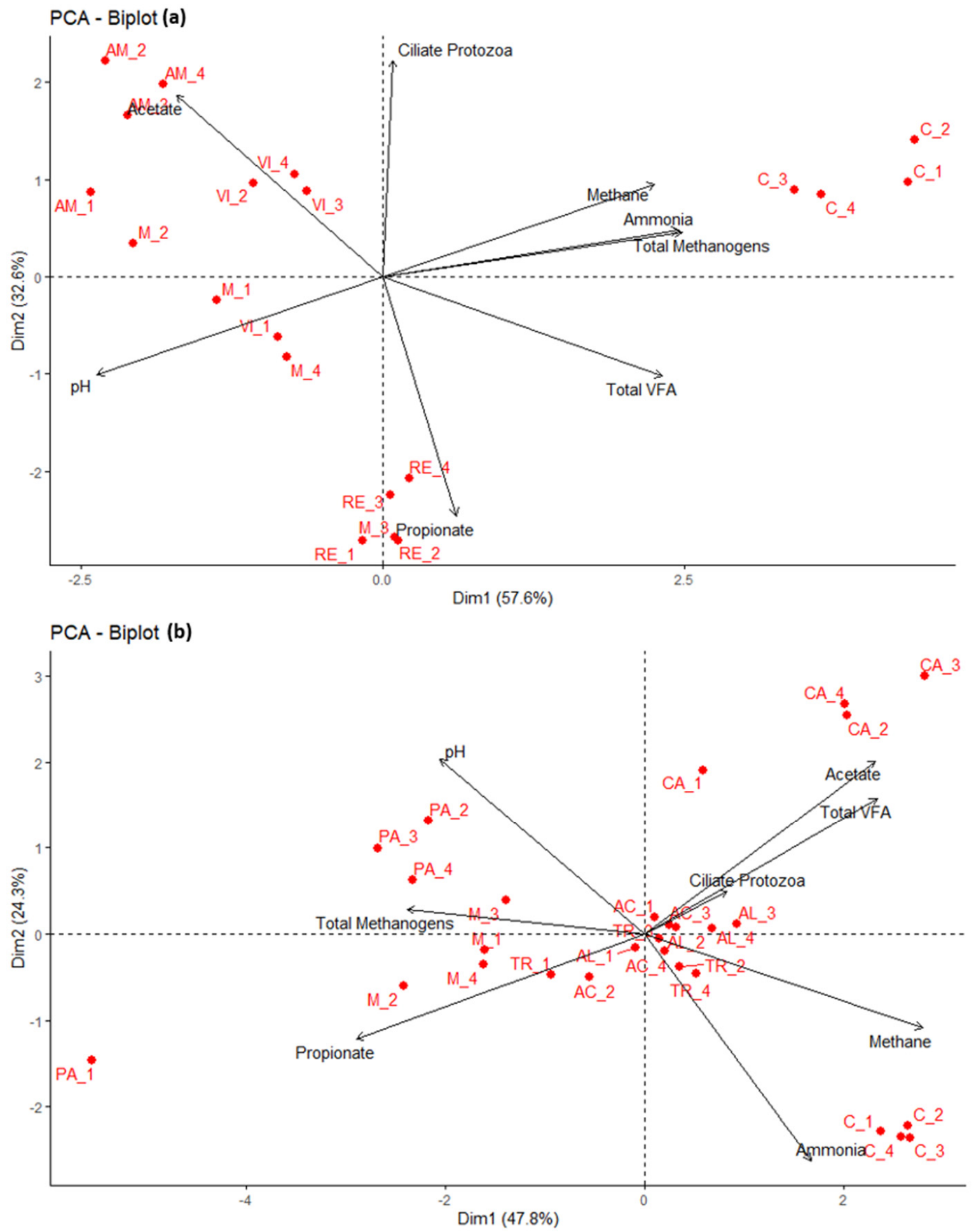

Figure 2. Principal components analysis of $\mathrm{CH}_{4}$ production, microbial diversity, and fermentation parameters in control and tested plant extracts during cycle 1 (a) and cycle 2 (b). Percentages of variation explained by PC1 and PC2 are indicated on the respective axes. C- control; M-monensin; VI-Vitex negundo; AM-Amelanchier asiatica; RE-Reynoutria sachalinensis; TR-Tribulus terrestris; AL-Alnus japonica; PA-Pharbitis nil; AC-Acer truncatum; CA-Carpinus tschonoskii. 
Table 6. Contents of phenolic fractions and total saponins in extracts ( $\mathrm{mg} / \mathrm{g}$ crude extract; analytical replicate $=3$ ).

\begin{tabular}{|c|c|c|c|c|c|c|}
\hline Plant Species & Total Phenols & $\begin{array}{r}\text { Non-Tannin } \\
\text { Phenols }\end{array}$ & Total Tannins & $\begin{array}{r}\text { Condensed } \\
\text { Tannins }\end{array}$ & $\begin{array}{r}\text { Hydrolysable } \\
\text { Tannins }\end{array}$ & Total Saponins \\
\hline Vitex negundo & 93.8 & 2.7 & 91.1 & 10.0 & 81.1 & 216.0 \\
\hline $\begin{array}{l}\text { Amelanchier } \\
\text { asiatica }\end{array}$ & 297.5 & 9.9 & 287.6 & 48.4 & 239.2 & 250.6 \\
\hline $\begin{array}{l}\text { Reynoutria } \\
\text { sachalinensis }\end{array}$ & 213.0 & 4.6 & 208.4 & 19.3 & 189.0 & 243.3 \\
\hline $\begin{array}{l}\text { Tribulus } \\
\text { terrestris }\end{array}$ & 11.9 & 0.4 & 11.5 & - & 11.5 & 115.8 \\
\hline Pharbitis nil & 2.4 & 0.1 & 2.4 & - & 2.4 & 70.5 \\
\hline Alnus japonica & 257.9 & 2.9 & 255.0 & 4.9 & 250.1 & 165.2 \\
\hline Acer truncatum & 267.5 & 8.6 & 258.9 & 43.2 & 215.7 & 242.8 \\
\hline $\begin{array}{l}\text { Carpinus } \\
\text { tschonoskii }\end{array}$ & 291.5 & 6.1 & 285.4 & 0.9 & 284.6 & 141.5 \\
\hline
\end{tabular}

Similarly, the decrease in $\mathrm{NH}_{3}-\mathrm{N}$ might be related to proteolysis inhibition through the formation of insoluble tannin-protein complexes [56,57]. Getachew et al. [58] reported a decrease in protein degradation and $\mathrm{NH}_{3}-\mathrm{N}$ after supplementation with tannic acids. This finding suggests that the addition of a tannin-rich extract might minimise the degradability of protein in the rumen and exert beneficial effects similar to those that occur when ruminants are supplemented with rumen undegradable protein (reviewed in [59]). Hydrolysable tannins with low molecular weight and less structural variability than condensed tannins result in more consistent reduction of $\mathrm{CH}_{4}$ due to gallic acid subunit binding to methanogens [60]. In the current study, the HT concentration provided by the extracts (1.15-1.35 g/100 g DM) was comparable with the level (1.43 g/100 g DM) supplemented in the study by Aboagye et al. [60], who observed a $9 \%$ decrease in $\mathrm{CH}_{4}$ yield. In addition, Jayanegara et al. [61] showed that HTs decrease the methanogen population and microbes, which provide $\mathrm{H}_{2}$ to a greater extent, compared to condensed tannins. Pure saponins and saponin-containing plants or extracts have inhibitory effects on protozoans (reviewed in [62]), which contribute to $\mathrm{CH}_{4}$ production via interspecific $\mathrm{H}_{2}$ transfer to methanogens [63]. In the current study, the abundances of total methanogens in VI, AM, and RE decreased $(p<0.001)$, as did ciliated protozoa in VI and RE $(p<0.001)$, compared to the control (Table 4). These findings clearly showed the effects of HTs and TSs on $\mathrm{H}_{2}$ and $\mathrm{CH}_{4}$ production, which thereby affect total gas production. These findings were supported by stronger negative $(\tau=-0.51, p=0.070)$ and positive $(\tau=0.64, p<0.05)$ correlations between TS content and $\mathrm{CH}_{4}$ production, and protozoan abundance and gas production, respectively (Table 7). However, $\mathrm{AL}, \mathrm{AC}$, and $\mathrm{CA}$ reduced $\mathrm{CH}_{4}$ without any negative effects on methanogens or the protozoan population, compared to the control (Table 5). Expression analysis of methyl-co reductase $(M C R)$ gene can provide a better understanding of complex methanogenesis processes than methanogen abundance analyses based on $16 \mathrm{~s}$ rDNA [64]. Other studies have also demonstrated that $\mathrm{CH}_{4}$ production is not correlated with methanogens abundance, but with its composition (reviewed in [65]). Furthermore, saponins may decrease the activities of $\mathrm{CH}_{4}$ producing genes or the rate of $\mathrm{CH}_{4}$ production in methanogenic cells [66], suggesting that PSMs from different sources have different effects on microbes and methanogenesis [67]. However, directly or indirectly inhibiting $\mathrm{CH}_{4}$ production entails a change in the VFA profile, mostly favouring greater propionate production [68]. Gram-positive ruminal bacteria generally produce acetate and butyrate, while Gram-negative bacteria produce propionate [69]. The decrease in $\mathrm{CH}_{4}$ production caused by most of the tested extracts in this experiment, without any changes in the proportions of individual VFAs (except PA), suggests broad spectral antibacterial activities of PSMs targeting Gram-positive and negative bacteria. However, no negative effects were observed on selected microbes, such as R. flavefaciens and R. albus, in this experiment. Some studies have reported that PSMs target other ruminal microbes with minimal effects on Ruminococcus spp. (reviewed in [46]). 
Table 7. Correlation coefficients between plant secondary metabolites, fermentation parameters, and microbial abundances (extract $=8$ ).

\begin{tabular}{|c|c|c|c|c|c|c|c|c|c|c|c|}
\hline & $\begin{array}{c}\text { Ciliate } \\
\text { Protozoa }\end{array}$ & $\begin{array}{c}\text { Total } \\
\text { Methanogens }\end{array}$ & $\begin{array}{c}\text { F. } \\
\text { succinogenes }\end{array}$ & $\begin{array}{c}R . \\
\text { flavefaciens }\end{array}$ & $\begin{array}{c}\text { Total } \\
\text { Saponins }\end{array}$ & $\begin{array}{c}\text { Total } \\
\text { Tannins }\end{array}$ & $\mathrm{C}_{3}(\%)$ & $\mathrm{C}_{2}(\%)$ & $\begin{array}{l}\text { Total VFAs } \\
\quad(\mathrm{mM})\end{array}$ & $\begin{array}{c}\mathrm{CH}_{4} \\
(\mathrm{mmol} / \mathrm{g} \\
\mathrm{DM})\end{array}$ & $\begin{array}{c}\text { Total Gas } \\
\text { (mmol/g } \\
\text { DM) }\end{array}$ \\
\hline $\mathrm{pH}$ & 0.43 & 0.40 & $-0.59^{\dagger}$ & 0.28 & -0.35 & -0.04 & -0.43 & -0.67 * & $0.59^{\dagger}$ & 0.67 * & $0.51^{\dagger}$ \\
\hline $\begin{array}{c}\text { Total gas } \\
(\mathrm{mmol} / \mathrm{g} \mathrm{DM})\end{array}$ & 0.64 * & 0.18 & -0.07 & 0.57 * & 0.00 & 0.36 & -0.71 * & -0.29 & 0.14 & 0.57 * & \\
\hline $\mathrm{CH}_{4}(\mathrm{mmol} / \mathrm{g} \mathrm{DM})$ & $0.50^{\dagger}$ & 0.33 & -0.36 & 0.43 & $-0.53^{\dagger}$ & -0.07 & -0.57 * & -0.43 & 0.57 * & & \\
\hline Total VFAs (mM) & 0.36 & $0.55+$ & -0.79 * & 0.29 & -0.71 * & -0.21 & -0.43 & -0.43 & & & \\
\hline $\mathrm{C}_{2}(\%)$ & -0.36 & -0.47 & $0.64 *$ & 0.14 & $0.57^{*}$ & 0.36 & 0.00 & & & & \\
\hline Total tannins & 0.14 & -0.11 & 0.29 & $0.50^{+}$ & $0.50^{\dagger}$ & & & & & & \\
\hline Total saponins & -0.21 & -0.62 * & 0.79 & 0.00 & & & & & & & \\
\hline R. flavefaciens & 0.36 & 0.40 & -0.07 & & & & & & & & \\
\hline F. succinogenes & -0.29 & $-0.62 *$ & & & & & & & & & \\
\hline Total methanogens & -0.04 & & & & & & & & & & \\
\hline
\end{tabular}


Despite the ban on the non-therapeutic use of monensin in the Republic of Korea, it remains one of the most commonly used ionophores in ruminants in other countries. Monensin supplementation has been associated with decreased methanogenesis accompanied by improved feed digestibility, increased propionate synthesis, and decreased $\mathrm{NH}_{3}-\mathrm{N}$ production [70]. A recent study [71] also showed a decrease in $\mathrm{CH}_{4}$ production coupled with a decrease in $\mathrm{H}_{2}$-producing microorganisms (e.g., protozoa, fungi, and Gram-positive Firmicutes) after supplementation with monensin. Intriguingly, in the current study, the decrease in $\mathrm{CH}_{4}$ production caused by PA alone was accompanied by decreases in protozoan abundance and $\mathrm{NH}_{3}-\mathrm{N}$ concentration, as well as an increase in the proportion of propionate, similar to the effect of monensin (Table 5).

Principal component analysis grouped PA and monensin, explaining $47.8 \%$ of the variation from their respective controls (Figure $2 \mathrm{~b}$ ). The PCA analysis also exhibited a strong correlation of propionate towards PA and monensin, further supporting our statement. The observed effect of PA with a very low concentration of TSs and near absence of HTs suggests the presence of other potentially bioactive compounds in PA. GC-MS analysis revealed the presence of a heterogeneous mixture, dominated by polyunsaturated fatty acids (Table 8). Seeds of $P$. nil had greater concentrations of 9,12-octadecadienoic acid (Z,Z)- (23\%), commonly known as linoleic acid (18:2), followed by 9,12-octadecadienoic acid (Z,Z)-,2,3-dihydroxypropyl ester (18\%) commonly known as alpha-glyceryl linoleate. Overall, $60 \%$ of the compounds identified were classified either as fatty acids or fatty acid amides. A meta-analysis by Patra et al. [19] established negative associations between total dietary polyunsaturated fatty acid concentrations and $\mathrm{CH}_{4}, \mathrm{VFAs}$, and $\mathrm{NH}_{3}-\mathrm{N}$ production in the rumen. The effects of polyunsaturated fatty acids on $\mathrm{CH}_{4}$ production were attributed to the change in $\mathrm{H}_{2}$ thermodynamics in the rumen, caused by inhibition of protozoa, biohydrogenation of unsaturated fatty acids, and increased production of propionic acid, which compete with methanogenesis for metabolic $\mathrm{H}_{2}$ [72,73]. A strong negative association $(\tau=-0.51, p=0.070)$ was noted between protozoan abundance and propionate proportion in the current study. A meta-analysis by Guyader [74] reported a decrease in protozoan abundances in experiments supplemented lipids on ruminants' diet, which was due to changes in membrane permeability, resulting in cell lysis [75]. In addition, Dohme et al. [76] reported a detrimental effect of linoleic acid (18:2) on the protozoan and total bacterial populations. This is consistent with the decreased $(p<0.001)$ abundance of the ciliated protozoa, $R$. flavefaciens and F. succinogens in PA, in the current study. However, complete metabolite profile of PA using chromatographic techniques with proper derivatization procedures would give deeper understanding of the compound responsible for the action. Moreover, enrichment of dietary linoleic acid (18:2), a precursor of bioactive conjugated linoleic acids [77], suggested that PA seeds might be a promising feed additive for ruminants. In addition, PA seeds have been widely used in Korean and Chinese traditional medicine for their roles in improving digestibility and intestinal motility (reviewed in [78]). Therefore, PA seeds could act as a source of fatty acids, probably replacing oil seeds that have been reported to decrease DM and neutral detergent fibre digestibility [19]. However, future in vitro or in vivo trials are needed to confirm their effects on rumen nutrient digestibility and animal performance, since the protozoal defaunation was associated with decrease in rumen organic matter digestibility and specifically NDF and ADF digestibility [79]. 
Table 8. Bioactive compounds in ethanolic extracts from seeds of Pharbitis nil identified using GC-MS.

\begin{tabular}{|c|c|c|c|c|c|}
\hline RT (min) & Compound & Formula & MW (g/mol) & Class & Area (\%) \\
\hline 7.29 & $\begin{array}{c}\text { Ethanone, } \\
\text { 1-(2-hydroxy-5-methylphenyl)- }\end{array}$ & $\mathrm{C}_{9} \mathrm{H}_{10} \mathrm{O}$ & 150.2 & $\begin{array}{c}\text { Alkyl- } \\
\text { phenylketone }\end{array}$ & 6.2 \\
\hline 8.49 & $\begin{array}{l}\text { (3-Nitrophenyl) methanol, } \\
\text { n-propyl ether }\end{array}$ & $\mathrm{C}_{10} \mathrm{H}_{13} \mathrm{NO}_{3}$ & 195.2 & Aromatic ether & 11.9 \\
\hline 12.23 & $\begin{array}{c}\text { Benzenepropanoic } \\
\text { acid,3,5-bis(1,1-dimethylethyl)- } \\
\text { 4-hydroxy-, } \\
\text { methyl ester }\end{array}$ & $\mathrm{C}_{18} \mathrm{H}_{28} \mathrm{O}_{3}$ & 292.4 & Alkyl ester & 6.6 \\
\hline 12.31 & $\begin{array}{l}\text { 1-(+)-Ascorbic acid } \\
\text { 2,6-dihexadecanoate }\end{array}$ & $\mathrm{C}_{38} \mathrm{H}_{68} \mathrm{O}_{8}$ & 652.9 & Fatty acid ester & 6.1 \\
\hline 13.44 & $\begin{array}{l}\text { 9,12-Octadecadienoic } \\
\text { acid }(Z, Z)-\end{array}$ & $\mathrm{C}_{18} \mathrm{H}_{32} \mathrm{O}_{2}$ & 280.4 & PUFA $^{1}$ & 23.5 \\
\hline 14.69 & $\begin{array}{l}\text { 7,10-Hexadecadienoic acid, } \\
\text { DMOX derivative }\end{array}$ & $\mathrm{C}_{16} \mathrm{H}_{28} \mathrm{O}_{2}$ & 252.4 & LCFA $^{2}$ & 9.8 \\
\hline 15.13 & 9-Octadecenamide, (Z)- & $\mathrm{C}_{18} \mathrm{H}_{35} \mathrm{NO}$ & 281.5 & Fatty amide & 5.5 \\
\hline 16.63 & $\begin{array}{l}\text { 2,3-Dihydroxypropyl } \\
\text { hexadecanoate }\end{array}$ & $\mathrm{C}_{19} \mathrm{H}_{38} \mathrm{O}_{4}$ & 330.5 & Monoacylglycerol & 6.7 \\
\hline 19.21 & $\begin{array}{c}\text { 9,12-Octadecadienoic acid } \\
(Z, Z)-, 2,3- \\
\text { dihydroxypropyl ester }\end{array}$ & $\mathrm{C}_{21} \mathrm{H}_{38} \mathrm{O}_{4}$ & 356.5 & Fatty amide & 18.5 \\
\hline 20.20 & 13-Docosenamide, $(Z)$ - & $\mathrm{C}_{22} \mathrm{H}_{43} \mathrm{NO}$ & 337.6 & Fatty amide & 2.3 \\
\hline 24.21 & ç-Sitosterol & $\mathrm{C}_{29} \mathrm{H}_{50} \mathrm{O}$ & 414.0 & Stigmastane & 2.9 \\
\hline
\end{tabular}

${ }^{1}$ Polyunsaturated fatty acid; ${ }^{2}$ Long chain fatty acid; MW molecular weight.

\section{Conclusions}

The extracts rich in phenolic compounds from stems of A. asiatica, fruit of $R$. sachalinensis, seeds of $T$. terrestris, leaves of $A$. japonica, stems and bark of $C$. tschonoskii, and stems of A. truncatum reduced $\mathrm{CH}_{4}$ production and fermentation rates in vitro. The negative effects on total gas and VFA production suggest the need to standardise the doses of plant extracts that are effective for inhibiting $\mathrm{CH}_{4}$ emissions with minimum adverse effects on fermentation. These supplemental plant extracts seem to decrease the output of ammonia from protein degradation, although the post ruminal nitrogen use efficiency is still remained to be elucidated in ruminants. Notably, the maximum reduction in $\mathrm{CH}_{4}$ production by the extracts from the seeds of $P$. nil, which are rich in linoleic acid (18:2) and other fatty acid amides, is a promising alternative to ionophores and oilseeds to mitigate $\mathrm{CH}_{4}$ emissions. In vivo trials must be conducted to elucidate the adaptation of rumen microbes to the seeds of P. nil over a prolonged feeding period.

Supplementary Materials: The following are available online at https:/ / www.mdpi.com/article/10 $.3390 /$ ani11041020/s1, Table S1: Relative changes in total gas production and methane concentration in gas in screening assay after $24 \mathrm{~h}$ of in vitro incubation (replicate $=3$ ).

Author Contributions: Conceptualization, K.H.K.; methodology, K.H.K.; formal analysis, R.B., S.A., R.I., S.J.L., Y.L., I.S.N.; data curation, R.B.; writing—original draft preparation, R.B.; writingreview and editing, R.B. and K.H.K.; software, R.B.; visualization, R.B.; funding acquisition, K.H.K.; supervision, M.B. All authors have read and agreed to the published version of the manuscript.

Funding: This study was supported by the National Institute of Animal Science, Ministry of Rural Development Administration, Republic of Korea (research project PJ01477802).

Institutional Review Board Statement: This study was conducted in accordance with the guidelines of the Animal Care and Use Committee of Seoul National University, Republic of Korea (approval number 160105-1).

Informed Consent Statement: Not applicable. 
Data Availability Statement: All data generated in this study are included in the manuscript and Supplementary Files.

Conflicts of Interest: The authors declare no conflict of interest.

\section{References}

1. Appuhamy, J.A.D.R.N.; France, J.; Kebreab, E. Models for predicting enteric methane emissions from dairy cows in North America, Europe, and Australia and New Zealand. Glob. Chang. Biol. 2016, 22, 3039-3056. [CrossRef]

2. Hristov, A.N.; Oh, J.; Firkins, J.L.; Dijkstra, J.; Kebreab, E.; Waghorn, G.; Makkar, H.P.S.; Adesogan, A.T.; Yang, W.; Lee, C.; et al. SPECIAL TOPICS-Mitigation of methane and nitrous oxide emissions from animal operations: I. A review of enteric methane mitigation options. J. Anim. Sci. 2013, 91, 5045-5069. [CrossRef]

3. Knapp, J.R.; Laur, G.L.; Vadas, P.A.; Weiss, W.P.; Tricarico, J.M. Invited review: Enteric methane in dairy cattle production: Quantifying the opportunities and impact of reducing emissions. J. Dairy Sci. 2014, 97, 3231-3261. [CrossRef]

4. Beauchemin, K.A.; Kreuzer, M.; O'Mara, F.; McAllister, T.A. Nutritional management for enteric methane abatement: A review. Aust. J. Exp. Agric. 2008, 48, 21-27. [CrossRef]

5. Buddle, B.M.; Denis, M.; Attwood, G.T.; Altermann, E.; Janssen, P.H.; Ronimus, R.S.; Pinares-Patiño, C.S.; Muetzel, S.; Neil Wedlock, D. Strategies to reduce methane emissions from farmed ruminants grazing on pasture. Vet. J. 2011, 188, 11-17. [CrossRef] [PubMed]

6. Patra, A.K. Enteric methane mitigation technologies for ruminant livestock: A synthesis of current research and future directions. Environ. Monit. Assess. 2012, 184, 1929-1952. [CrossRef] [PubMed]

7. Martin, C.; Morgavi, D.P.; Doreau, M. Methane mitigation in ruminants: From microbe to the farm scale. Animal 2010, 4, 351-365. [CrossRef] [PubMed]

8. Patra, A.; Park, T.; Kim, M.; Yu, Z. Rumen methanogens and mitigation of methane emission by anti-methanogenic compounds and substances. J. Anim. Sci. Biotechnol. 2017, 8. [CrossRef] [PubMed]

9. Hristov, A.N.; Oh, J.; Giallongo, F.; Frederick, T.W.; Harper, M.T.; Weeks, H.L.; Branco, A.F.; Moate, P.J.; Deighton, M.H.; Williams, S.R.O; ; et al. An inhibitor persistently decreased enteric methane emission from dairy cows with no negative effect on milk production. Proc. Natl. Acad. Sci. USA 2015, 112, 10663-10668. [CrossRef] [PubMed]

10. Vyas, D.; Alemu, A.W.; McGinn, S.M.; Duval, S.M.; Kindermann, M.; Beauchemin, K.A. The combined effects of supplementing monensin and 3-nitrooxypropanol on methane emissions, growth rate, and feed conversion efficiency in beef cattle fed high-forage and high-grain diets. J. Anim. Sci. 2018, 96, 2923-2938. [CrossRef] [PubMed]

11. Lee, H.-J.; Cho, S.-H.; Shin, D.; Kang, H.-S. Prevalence of Antibiotic Residues and Antibiotic Resistance in Isolates of Chicken Meat in Korea. Korean J. food Sci. Anim. Resour. 2018, 38, 1055-1063. [CrossRef] [PubMed]

12. Maron, D.F.; Smith, T.J.S.; Nachman, K.E. Restrictions on antimicrobial use in food animal production: An international regulatory and economic survey. Global. Health 2013, 9, 48. [CrossRef] [PubMed]

13. Dhanasekaran, D.K.; Dias-Silva, T.P.; Filho, A.L.A.; Sakita, G.Z.; Abdalla, A.L.; Louvandini, H.; Elghandour, M.M.M.Y. Plants extract and bioactive compounds on rumen methanogenesis. Agrofor. Syst. 2020, 94, 1541-1553. [CrossRef]

14. Klevenhusen, F.; Muro-Reyes, A.; Khiaosa-ard, R.; Metzler-Zebeli, B.U.; Zebeli, Q. A meta-analysis of effects of chemical composition of incubated diet and bioactive compounds on in vitro ruminal fermentation. Anim. Feed Sci. Technol. 2012, 176, 61-69. [CrossRef]

15. Patra, A.K.; Saxena, J. A new perspective on the use of plant secondary metabolites to inhibit methanogenesis in the rumen. Phytochemistry 2010, 71, 1198-1222. [CrossRef] [PubMed]

16. Moate, P.J.; Williams, S.R.O.; Grainger, C.; Hannah, M.C.; Ponnampalam, E.N.; Eckard, R.J. Influence of cold-pressed canola, brewers grains and hominy meal as dietary supplements suitable for reducing enteric methane emissions from lactating dairy cows. Anim. Feed Sci. Technol. 2011, 166-167, 254-264. [CrossRef]

17. Giger-Reverdin, S.; Morand-Fehr, P.; Tran, G. Literature survey of the influence of dietary fat composition on methane production in dairy cattle. Livest. Prod. Sci. 2003, 82, 73-79. [CrossRef]

18. Eugène, M.; Massé, D.; Chiquette, J.; Benchaar, C. Meta-analysis on the effects of lipid supplementation on methane production in lactating dairy cows. Can. J. Anim. Sci. 2008, 88, 331-334. [CrossRef]

19. Patra, A.K. The effect of dietary fats on methane emissions, and its other effects on digestibility, rumen fermentation and lactation performance in cattle: A meta-analysis. Livest. Sci. 2013, 155, 244-254. [CrossRef]

20. Bodas, R.; López, S.; Fernández, M.; García-González, R.; Rodríguez, A.B.; Wallace, R.J.; González, J.S. In vitro screening of the potential of numerous plant species as antimethanogenic feed additives for ruminants. Anim. Feed Sci. Technol. 2008, 145, 245-258. [CrossRef]

21. García-González, R.; López, S.; Fernández, M.; Bodas, R.; González, J.S. Screening the activity of plants and spices for decreasing ruminal methane production in vitro. Anim. Feed Sci. Technol. 2008, 147, 36-52. [CrossRef]

22. Macheboeuf, D.; Coudert, L.; Bergeault, R.; Lalière, G.; Niderkorn, V. Screening of plants from diversified natural grasslands for their potential to combine high digestibility, and low methane and ammonia production. Animal 2014, 8, 1797-1806. [CrossRef] [PubMed]

23. Kamra, D.N.; Patra, A.K.; Chatterjee, P.N.; Kumar, R.; Agarwal, N.; Chaudhary, L.C. Effect of plant extracts on methanogenesis and microbial profile of the rumen of buffalo: A brief overview. Aust. J. Exp. Agric. 2008, 48, 175-178. [CrossRef] 
24. Benchaar, C.; Greathead, H. Essential oils and opportunities to mitigate enteric methane emissions from ruminants. Anim. Feed Sci. Technol. 2011, 166-167, 338-355. [CrossRef]

25. Klop, G.; Van Laar-Van Schuppen, S.; Pellikaan, W.F.; Hendriks, W.H.; Bannink, A.; Dijkstra, J. Changes in in vitro gas and methane production from rumen fluid from dairy cows during adaptation to feed additives in vivo. Animal 2017, 11, 591-599. [CrossRef]

26. McDougall, E.I. Studies on ruminant saliva. 1. The composition and output of sheep's saliva. Biochem. J. 1948, 43, 99-109. [CrossRef]

27. Fedorah, P.M.; Hrudey, S.E. A simple apparatus for measuring gas production by methanogenic cultures in serum bottles. Environ. Technol. Lett. 1983, 4, 425-432. [CrossRef]

28. Chaney, A.L.; Marbach, E.P. Modified reagents for determination of urea and ammonia. Clin. Chem. 1962, 8, 130-132. [CrossRef]

29. Erwin, E.S.; Marco, G.J.; Emery, E.M. Volatile Fatty Acid Analyses of Blood and Rumen Fluid by Gas Chromatography. J. Dairy Sci. 1961, 44, 1768-1771. [CrossRef]

30. Bharanidharan, R.; Arokiyaraj, S.; Kim, E.B.; Lee, C.H.; Woo, Y.W.; Na, Y.; Kim, D.; Kim, K.H. Ruminal methane emissions, metabolic, and microbial profile of Holstein steers fed forage and concentrate, separately or as a total mixed ration. PLoS ONE 2018, 13, e0202446. [CrossRef] [PubMed]

31. Makkar, H.P.S. Quantification of Tannins in Tree and Shrub Foliage; Springer: Dordrecht, The Netherlands, 2003.

32. Singh, B.; Sahoo, A.; Sharma, R.; Bhat, T.K. Effect of polethylene glycol on gas production parameters and nitrogen disappearance of some tree forages. Anim. Feed Sci. Technol. 2005, 123-124, 351-364. [CrossRef]

33. Nguyen, V.T.; Bowyer, M.C.; Van Vuong, Q.; Altena, I.A.V.; Scarlett, C.J. Phytochemicals and antioxidant capacity of Xao tam phan (Paramignya trimera) root as affected by various solvents and extraction methods. Ind. Crops Prod. 2015, 67, 192-200. [CrossRef]

34. Skillman, L.C.; Toovey, A.F.; Williams, A.J.; Wright, A.D.G. Development and validation of a real-time PCR method to quantify rumen protozoa and examination of variability between Entodinium populations in sheep offered a hay-based diet. Appl. Environ. Microbiol. 2006, 72, 200-206. [CrossRef] [PubMed]

35. Livak, K.J.; Schmittgen, T.D. Analysis of relative gene expression data using real-time quantitative PCR and the 2- $\Delta \Delta C T$ method. Methods 2001, 25, 402-408. [CrossRef] [PubMed]

36. Denman, S.E.; McSweeney, C.S. Development of a real-time PCR assay for monitoring anaerobic fungal and cellulolytic bacterial populations within the rumen. FEMS Microbiol. Ecol. 2006, 58, 572-582. [CrossRef] [PubMed]

37. Wang, R.F.; Cao, W.W.; Cerniglia, C.E. PCR detection of Ruminococcus spp. in human and animal faecal samples. Mol. Cell. Probes 1997, 11, 259-265. [CrossRef] [PubMed]

38. Zhou, M.; Hernandez-Sanabria, E.; Le, L.G. Assessment of the microbial ecology of ruminal methanogens in cattle with different feed efficiencies. Appl. Environ. Microbiol. 2009, 75, 6524-6533. [CrossRef] [PubMed]

39. Husson, F.; Josse, J.; Le, S.; Maintainer, J.M. Multivariate exploratory data analysis and data mining. Cran 2020, 1, 1-130.

40. Jafari, S.; Ebrahimi, M.; Goh, Y.M.; Rajion, M.A.; Jahromi, M.F.; Al-Jumaili, W.S. Manipulation of rumen fermentation and methane gas production by plant secondary metabolites (saponin, tannin and essential oil)—A review of ten-year studies. Ann. Anim. Sci. 2019, 19, 3-29. [CrossRef]

41. Patra, A.K.; Saxena, J. Dietary phytochemicals as rumen modifiers: A review of the effects on microbial populations. Antonie van Leeuwenhoek 2009, 96, 363-375. [CrossRef]

42. Jayanegara, A.; Wina, E.; Takahashi, J. Meta-analysis on methane mitigating properties of saponin-rich sources in the Rumen: Influence of addition levels and plant sources. Asian-Australasian J. Anim. Sci. 2014, 27, 1426-1435. [CrossRef] [PubMed]

43. Santra, A.; Saikia, A.; Baruah, K.K. Scope of Rumen Manipulation Using Medicinal Plants To Mitigate Methane Production. J. Pharmacogn. 2012, 3, 115-120.

44. Feng, Z.H.; Cao, Y.F.; Gao, Y.X.; Li, Q.F.; Li, J.G. Effect of gross saponin of Tribulus terrestris on ruminal fermentation and methane production in vitro. J. Anim. Vet. Adv. 2012, 11, 2121-2125. [CrossRef]

45. Bergman, E.N. Energy contributions of volatile fatty acids from the gastrointestinal tract in various species. Physiol. Rev. 1990, 70, 567-590. [CrossRef] [PubMed]

46. Wallace, R.J. Antimicrobial properties of plant secondary metabolites. Proc. Nutr. Soc. 2004, 63, 621-629. [CrossRef] [PubMed]

47. Gu, R.; Rybalov, L.; Negrin, A.; Morcol, T.; Long, W.; Myers, A.K.; Isaac, G.; Yuk, J.; Kennelly, E.J.; Long, C. Metabolic Profiling of Different Parts of Acer truncatum from the Mongolian Plateau Using UPLC-QTOF-MS with Comparative Bioactivity Assays. J. Agric. Food Chem. 2019, 67, 1585-1597. [CrossRef] [PubMed]

48. Sati, S.C.; Sati, N.; Sati, O.P. Bioactive constituents and medicinal importance of genus Alnus. Pharmacogn. Rev. 2011, 5, 174-183. [CrossRef] [PubMed]

49. Yin, J.; Ahn, H.S.; Ha, S.Y.; Hwang, I.H.; Yoon, K.D.; Chin, Y.W.; Lee, M.W. Anti-skin ageing effects of phenolic compounds from Carpinus tschonoskii. Nat. Prod. Res. 2019, 33, 3317-3320. [CrossRef] [PubMed]

50. Chae, J.W.; Kim, J.S.; Jo, B.S.; Kang, S.A.; Park, H.J.; Joo, S.H.; Chun, S.S.; Cho, Y.J. Biological activity of ethanol extracts from Amelanchier asiatica fruits. J. Appl. Biol. Chem. 2011, 54, 238-243. [CrossRef]

51. Saklani, S.; Mishra, A.P.; Chandra, H.; Atanassova, M.S.; Stankovic, M.; Sati, B.; Shariati, M.A.; Nigam, M.; Khan, M.U.; Plygun, S.; et al. Comparative evaluation of polyphenol contents and antioxidant activities between ethanol extracts of vitex negundo and vitex trifolia L. Leaves by different methods. Plants 2017, 6, 45. [CrossRef]

52. Nawrot-Hadzik, I.; Granica, S.; Domaradzki, K.; Pecio, Ł.; Matkowski, A. Isolation and Determination of Phenolic Glycosides and Anthraquinones from Rhizomes of Various Reynoutria Species. Planta Med. 2018, 84, 1118-1126. [CrossRef] [PubMed] 
53. Yang, K.; Wei, C.; Zhao, G.Y.; Xu, Z.W.; Lin, S.X. Effects of dietary supplementing tannic acid in the ration of beef cattle on rumen fermentation, methane emission, microbial flora and nutrient digestibility. J. Anim. Physiol. Anim. Nutr. 2017, 101, 302-310. [CrossRef] [PubMed]

54. Hristov, A.N.; Ivan, M.; Neill, L.; McAllister, T.A. Evaluation of several potential bioactive agents for reducing protozoal activity in vitro. Anim. Feed Sci. Technol. 2003, 105, 163-184. [CrossRef]

55. Pope, P.B.; Smith, W.; Denman, S.E.; Tringe, S.G.; Barry, K.; Hugenholtz, P.; McSweeney, C.S.; McHardy, A.C.; Morrison, M. Isolation of Succinivibrionaceae implicated in low methane emissions from Tammar wallabies. Science 2011, 333, 646-648. [CrossRef] [PubMed]

56. McArt, S.H.; Spalinger, D.E.; Kennish, J.M.; Collins, W.B. A modified method for determining tannin-protein precipitation capacity using Accelerated Solvent Extraction (ASE) and microplate gel filtration. J. Chem. Ecol. 2006, 32, 1367-1377. [CrossRef] [PubMed]

57. Selje, N.; Hoffmann, E.M.; Muetzel, S.; Ningrat, R.; Wallace, R.J.; Becker, K. Results of a screening programme to identify plants or plant extracts that inhibit ruminal protein degradation. Br. J. Nutr. 2007, 98, 45-53. [CrossRef]

58. Getachew, G.; Pittroff, W.; Putnam, D.H.; Dandekar, A.; Goyal, S.; DePeters, E.J. The influence of addition of gallic acid, tannic acid, or quebracho tannins to alfalfa hay on in vitro rumen fermentation and microbial protein synthesis. Anim. Feed Sci. Technol. 2008, 140, 444-461. [CrossRef]

59. Gulati, S.K.; Garg, M.R.; Scott, T.W. Rumen protected protein and fat produced from oilseeds and/or meals by formaldehyde treatment; their role in ruminant production and product quality: A review. Aust. J. Exp. Agric. 2005, 45, 1189-1203. [CrossRef]

60. Aboagye, I.A.; Oba, M.; Koenig, K.M.; Zhao, G.Y.; Beauchemin, K.A. Use of gallic acid and hydrolyzable tannins to reduce methane emission and nitrogen excretion in beef cattle fed a diet containing alfalfa silage. J. Anim. Sci. 2019, 97, $2230-2244$. [CrossRef] [PubMed]

61. Jayanegara, A.; Goel, G.; Makkar, H.P.S.; Becker, K. Divergence between purified hydrolysable and condensed tannin effects on methane emission, rumen fermentation and microbial population in vitro. Anim. Feed Sci. Technol. 2015, 209, 60-68. [CrossRef]

62. Patra, A.K.; Saxena, J. The effect and mode of action of saponins on the microbial populations and fermentation in the rumen and ruminant production. Nutr. Res. Rev. 2009, 22, 204-219. [CrossRef]

63. Newbold, C.J.; Lassalas, B.; Jouany, J.P. The importance of methanogens associated with ciliate protozoa in ruminal methane production in vitro. Lett. Appl. Microbiol. 1995, 21, 230-234. [CrossRef] [PubMed]

64. Shi, W.; Moon, C.D.; Leahy, S.C.; Kang, D.; Froula, J.; Kittelmann, S.; Fan, C.; Deutsch, S.; Gagic, D.; Seedorf, H.; et al. Methane yield phenotypes linked to differential gene expression in the sheep rumen microbiome. Genome Res. 2014, 24, 1517-1525. [CrossRef] [PubMed]

65. Abbott, D.W.; Aasen, I.M.; Beauchemin, K.A.; Grondahl, F.; Gruninger, R.; Hayes, M.; Huws, S.; Kenny, D.A.; Krizsan, S.J.; Kirwan, S.F.; et al. Seaweed and seaweed bioactives for mitigation of enteric methane: Challenges and opportunities. Animals 2020, 10, 2432. [CrossRef] [PubMed]

66. Guo, Y.Q.; Liu, J.X.; Lu, Y.; Zhu, W.Y.; Denman, S.E.; McSweeney, C.S. Effect of tea saponin on methanogenesis, microbial community structure and expression of mcrA gene, in cultures of rumen micro-organisms. Lett. Appl. Microbiol. 2008, 47, 421-426. [CrossRef] [PubMed]

67. Aboagye, I.A.; Beauchemin, K.A. Potential of molecular weight and structure of tannins to reduce methane emissions from ruminants: A review. Animals 2019, 9, 856. [CrossRef] [PubMed]

68. Van Nevel, C.J. Control of rumen methanogenesis. Environ. Monit. Assess. 1996, 42, 73-97. [CrossRef] [PubMed]

69. Stewart, C.S.; Flint, H.J.; Bryant, M.P. The rumen bacteria. In The Rumen Microbial Ecosystem; Hobson, P.N., Stewart, C.S., Eds.; Springer: Dordrecht, The Netherlands, 1997; pp. 10-72. [CrossRef]

70. Russell, J.B.; Houlihan, A.J. Ionophore resistance of ruminal bacteria and its potential impact on human health. FEMS Microbiol. Rev. 2003, 27, 65-74. [CrossRef]

71. Shen, J.; Liu, Z.; Yu, Z.; Zhu, W. Monensin and nisin affect rumen fermentation and microbiota differently in vitro. Front. Microbiol. 2017, 8, 1111. [CrossRef] [PubMed]

72. Jenkins, T.C.; Wallace, R.J.; Moate, P.J.; Mosley, E.E. Board-Invited Review: Recent advances in biohydrogenation of unsaturated fatty acids within the rumen microbial ecosystem. J. Anim. Sci. 2008, 86, 397-412. [CrossRef]

73. Li, Z.; Deng, Q.; Liu, Y.; Yan, T.; Li, F.; Cao, Y.; Yao, J. Dynamics of methanogenesis, ruminal fermentation and fiber digestibility in ruminants following elimination of protozoa: A meta-analysis. J. Anim. Sci. Biotechnol. 2018, 9, 89. [CrossRef] [PubMed]

74. Guyader, J.; Eugène, M.; Nozière, P.; Morgavi, D.P.; Doreau, M.; Martin, C. Influence of rumen protozoa on methane emission in ruminants: A meta-analysis approach. Animal 2014, 8, 1816-1825. [CrossRef] [PubMed]

75. Goel, G.; Puniya, A.K.; Aguilar, C.N.; Singh, K. Interaction of gut microflora with tannins in feeds. Naturwissenschaften 2005, 92, 497-503. [CrossRef] [PubMed]

76. Dohme, F.; Machmüller, A.; Wasserfallen, A.; Kreuzer, M. Ruminal methanogenesis as influenced by individual fatty acids supplemented to complete ruminant diets. Lett. Appl. Microbiol. 2008, 32, 47-51. [CrossRef]

77. Shingfield, K.J.; Wallace, R.J. Synthesis of conjugated linoleic acid in ruminants and humans. RSC Catal. Ser. 2014, 1-65. [CrossRef]

78. Kim, Y.S.; Kim, J.W.; Ha, N.Y.; Kim, J.; Ryu, H.S. Herbal Therapies in Functional Gastrointestinal Disorders: A Narrative Review and Clinical Implication. Front. Psychiatry 2020, 11, 601. [CrossRef] [PubMed]

79. Newbold, C.J.; De la Fuente, G.; Belanche, A.; Ramos-Morales, E.; McEwan, N.R. The role of ciliate protozoa in the rumen. Front. Microbiol. 2015, 6, 1313. [CrossRef] [PubMed] 